\title{
Revisiting the role of mitochondria in spinal muscular atrophy
}

\author{
Rachel James $^{1} \cdot$ Helena Chaytow ${ }^{1,2} \cdot$ Leire M. Ledahawsky $^{1} \cdot$ Thomas H. Gillingwater $^{1,2} \mathbb{C}$
}

Received: 1 December 2020 / Revised: 22 February 2021 / Accepted: 23 March 2021 / Published online: 5 April 2021

(C) The Author(s) 2021

\begin{abstract}
Spinal muscular atrophy (SMA) is an autosomal recessive motor neuron disease of variable clinical severity that is caused by mutations in the survival motor neuron $1(S M N 1)$ gene. Despite its name, SMN is a ubiquitous protein that functions within and outside the nervous system and has multiple cellular roles in transcription, translation, and proteostatic mechanisms. Encouragingly, several SMN-directed therapies have recently reached the clinic, albeit this has highlighted the increasing need to develop combinatorial therapies for SMA to achieve full clinical efficacy. As a subcellular site of dysfunction in SMA, mitochondria represents a relevant target for a combinatorial therapy. Accordingly, we will discuss our current understanding of mitochondrial dysfunction in SMA, highlighting mitochondrial-based pathways that offer further mechanistic insights into the involvement of mitochondria in SMA. This may ultimately facilitate translational development of targeted mitochondrial therapies for SMA. Due to clinical and mechanistic overlaps, such strategies may also benefit other motor neuron diseases and related neurodegenerative disorders.
\end{abstract}

Keywords Survival motor neuron · Mitochondrial dysfunction · Mitophagy $\cdot$ Combinatorial therapy $\cdot$ Motor neuron disease $\cdot$ Neurodegenerative disorders

$\begin{array}{ll}\text { Abbreviations } \\ \text { ARX-2 } & \text { Actin-related protein } 2 \\ \text { BCAA } & \text { Branched-chain amino acid } \\ \text { Bcat2 } & \text { BCAA transaminase 2 } \\ \text { ETC } & \text { Electron transport chain } \\ \text { HIF } & \text { Hypoxia-inducible factor } \\ \text { 4-HNE } & \text { 4-Hydroxynonenal } \\ \text { hnRNP } & \text { Heterogeneous nuclear ribonucleoprotein } \\ \text { IMM } & \text { Inner mitochondrial membrane } \\ \text { MFN2 } & \text { Mitofusin 2 } \\ \text { MMP } & \text { Mitochondrial membrane potential } \\ \text { mtDNA } & \text { Mitochondrial DNA } \\ \text { NAIP } & \text { Neuronal apoptosis inhibitory protein (or NLR } \\ & \text { family apoptosis inhibitor protein) } \\ \text { NCALD } & \text { Neurocalcin delta } \\ \text { OMM } & \text { Outer mitochondrial membrane } \\ \text { PGAM5 } & \text { PGAM family member } 5\end{array}$

Thomas H. Gillingwater

t.gillingwater@ed.ac.uk

1 Edinburgh Medical School: Biomedical Sciences, University of Edinburgh, Edinburgh EH8 9XD, UK

2 Euan MacDonald Centre for Motor Neurone Disease Research, University of Edinburgh, Edinburgh EH16 4SB, UK

$\begin{array}{ll}\text { PGK1 } & \text { Phosphoglycerate kinase 1 } \\ \text { ROS } & \text { Reactive oxygen species } \\ \text { SMA } & \text { Spinal muscular atrophy } \\ \text { SMN } & \text { Survival motor neuron } \\ \text { TIM } & \text { Translocase of the inner membrane } \\ \text { TOM } & \text { Translocase of the outer membrane } \\ \text { tRNA } & \text { Transfer RNA } \\ \text { UBA1 } & \text { Ubiquitin-like modifier activating enzyme 1 } \\ \text { VDAC1 } & \text { Voltage-dependent anion-selective channel 1 } \\ \text { Vps13D } & \text { Vacuolar protein sorting 13 homolog D }\end{array}$

\section{Introduction}

Spinal muscular atrophy (SMA) is a monogenetic motor neuron disease on the verge of being redefined, largely due to notable therapeutic breakthroughs over the last decade. SMA is caused by mutations in the survival motor neuron 1 $(S M N 1)$ gene, leading to loss of its SMN protein product [1] (Fig. 1a). Due to a complex, highly repeated DNA sequence, the human genome contains an inverted duplication in the $S M N$ region of chromosome 5, producing the near-identical duplicate gene, $S M N 2$. A single nucleotide polymorphism in exon 7 of SMN2 leads to removal of exon 7 in $80-90 \%$ of transcripts; this truncated transcript is unstable and quickly 


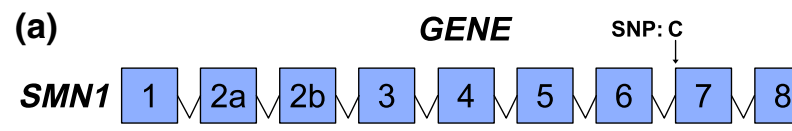

Mutated in SMA $\rightarrow$ complete loss of expression
PROTEIN

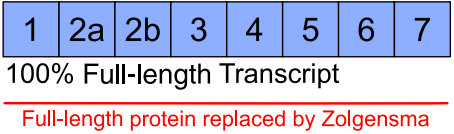

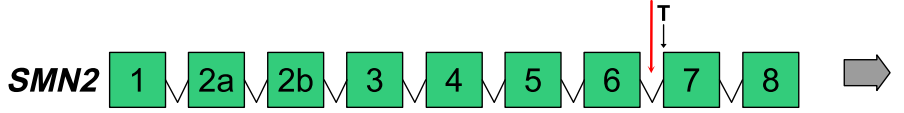

\section{\begin{tabular}{l|l|l|l|l|l|l|l|}
1 & $2 \mathrm{a}$ & $2 \mathrm{~b}$ & 3 & 4 & 5 & 6 & 7 \\
\hline
\end{tabular} \\ 10\% Full-length Transcript}

\begin{tabular}{|l|l|l|l|l|l|l|l|}
1 & $2 \mathrm{a}$ & $2 \mathrm{~b}$ & 3 & 4 & 5 & 6 & 8 \\
\hline
\end{tabular}

$90 \%$ Truncated Transcript $(\Delta 7)$

(b)

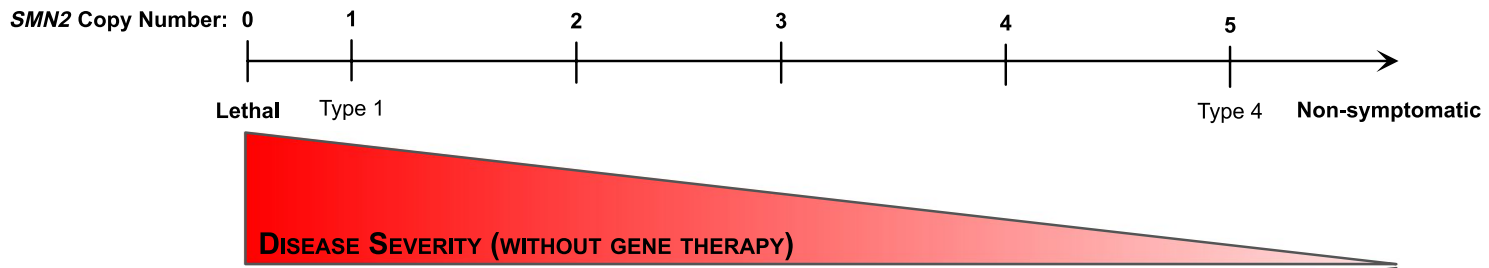

SMN PROTEIN EXPRESSION

Fig. 1 Summary of the genetics of spinal muscular atrophy and their correlation to clinical symptoms. a Survival motor neuron $(S M N)-1$ encodes the SMN protein and is mutated in spinal muscular atrophy (SMA). SMN2 is a near-identical gene with a single nucleotide polymorphism (SNP) at the beginning of exon 7, leading to exon 7 exclusion in the majority of SMN2 mRNA transcripts. This truncated protein is quickly degraded. Three currently licenced therapies for SMA (shown in red) aim to increase SMN protein expression,

degraded [2,3]. SMN2 is therefore unable to compensate for mutated SMN1 leading to suboptimal levels of SMN protein. Humans have variable copy numbers of the SMN2 gene (again due to the repeating nature of this region of chromosome 5), and increased copy numbers of $S M N 2$ can partially compensate for $S M N 1$ mutation. This is reflected in time of onset and severity of symptoms in patients [4].

Patients have traditionally been grouped into sub-types of SMA with disease severity and motor milestones influenced by $S M N 2$ copy number [5] (Fig. 1b). Type 0 patients have one copy of $S M N 2$, with prenatal motor weakness, paralysis, and death weeks after birth. Type 1 patients are more common, with two copies of SMN2 and obvious motor symptoms within the first few months of life as they do not develop head control. Untreated, Type 1 patients have a life expectancy of around 2 years. Patients with three copies of SMN2 are characterised as Type 2, with symptom onset between 6 months and 2 years and development of motor skills such as sitting and possibly standing. Type 3 patients develop motor symptoms after 18 months old, have three or four copies of $S M N 2$, and are likely to reach the motor milestone of unassisted walking and have a normal lifespan either by introducing an exogenous copy of SMN1 (Zolgensma ${ }^{\circledR}$ ) or promoting exon 7 inclusion in SMN2 transcripts (Spinraza ${ }^{\circledR}$ and Evrysdi $^{\circledR}$ ), thereby producing full-length SMN. b As SMN2 copy number increases, full-length SMN protein expression increases and is inversely proportional to disease severity. Type 1 patients have one copy of $S M N 2$, with copy numbers increasing until Type 4 patients, who have the mildest symptoms

[6]. These SMA patient sub-types are based on the natural history of the disease. However, we have reached a new therapeutic era for SMA, with the approval and licencing of three genetic therapies: Spinraza ${ }^{\circledR}$ is an antisense oligonucleotide that modulates splicing of $S M N 2$ to increase SMN production [7]; Zolgensma ${ }^{\circledR}$ is a viral vector that introduces a second copy of SMN1 to boost SMN expression [8]; and Evrysdi ${ }^{\circledR}$ is a small molecule that also alters $S M N 2$ splicing [9]. Treatment with any one of these therapies significantly extends the time to invasive respiratory ventilation and life expectancy for many patients with SMA (most trials to date have been conducted in Type 1 patients). However, emerging evidence from patients treated with these "SMN-replacement" therapies reveals an ongoing loss of function and continued presence of neuromuscular symptoms [10]. Children treated earlier, before motor symptoms develop, have the highest chance of achieving successive motor milestones, while children who are treated at a later disease time point continue to be at high risk of needing supported ventilation [11] and enteral feeding [12]. The effect of these therapies in adults with Types $2 / 3$ SMA is even less clear, not least because of the heterogeneity of clinical symptoms and small 
patient group sizes. Nevertheless, there is some evidence of stabilisation or even improvement in motor symptoms in adult patients [13]. Thus, there is a growing body of evidence indicating that replacing SMN protein levels in patients can only go part-way to relieving symptoms due to affected tissues being too far down the degeneration pathway [14]. SMN-independent therapies are therefore needed to act in concert with SMN-replacement and further benefit patients with SMA (e.g., "SMN + therapies" [15]).

As a multi-systemic disorder, SMA affects many cell types since SMN protein is ubiquitously expressed throughout the body [16]. Undoubtedly though, motor neurons and muscle cells are a predominant site of cellular pathology. Neurons and muscle cells are in turn two of the most energydependent cells within the body; therefore, as mitochondria are primarily known for their role in energy and metabolic pathways, it is not hard to envision their involvement in SMA based upon this role. Yet mitochondria are no longer viewed solely as the 'powerhouse' of the cell and are implicated in many other aspects of cellular function that intersect with the aetiology of SMA and known roles of the SMN protein. Initially, SMN protein was reported to function in transcriptional processes but is now known to also play roles in protein translation and related proteostatic mechanisms such as autophagy and ubiquitination [17]. Dissecting these varied functions of SMN across a disease of heterogenous expression has been made possible through the development of animal models of varying severity (e.g., severe, intermediate, and mild mouse models, reflecting Types 1, 2, and 3/4 in patients, respectively) $[18,19]$. By providing an overview of the mitochondrial dysfunction in SMA, our intention is to guide molecular mechanistic understanding and aid translational targeting of mitochondria, which offer many routes for complementary therapeutic interventions to current SMNreplacement therapies.

\section{Mitochondrial dysfunction in SMA}

\section{Mitochondrial respiration and oxidative phosphorylation}

Mitochondrial respiration refers to the set of metabolic reactions and processes that require oxygen to generate ATP. Of this process, oxidative phosphorylation mediated via the electron transport chain (ETC; complexes I-V) is the final step. Unsurprisingly, energetic disturbances suggestive of underlying mitochondrial dysfunction are present in muscle biopsies from patients with SMA (Table 1). Overall, SMA muscle pathology is associated with a decrease in mitochondrial respiration, reduced activity in oxidative phosphorylation enzymes, and a concomitant reduction in expression of both nuclear-encoded and mitochondrial-encoded subunits of the oxidative phosphorylation machinery [20-24]. This energetic disturbance has since been corroborated in various animal and cell culture models [25-31]. Interestingly, SMA patient-derived myoblasts and differentiated myotubes showed an intrinsic energy deficit characterised by increased reliance on mitochondrial ATP production [29], that may be borne out in patients with Type 3 SMA [32]. Taken together, these studies reveal a deficit in oxidative phosphorylation activity in tissue and cells relevant to SMA pathology. Moreover, these deficits are evident across the clinical spectrum of SMA and are not solely a feature of the more severe (i.e., Type 1) phenotype.

\section{Reactive oxygen species and oxidative stress}

As by-products of oxidative phosphorylation, as well as other mitochondrial and cellular biochemical reactions, reactive oxygen species (ROS) is an umbrella term for a group of molecular species. ROS are well-known for their pathological role in oxidative processes and resultant oxidative stress, but also play a physiological role in cell signalling and homeostasis [33]. Although neither ROS production nor oxidative stress are exclusively mitochondrial functions, both are underpinned by mitochondria and are a classic example of the double-edged role that mitochondria often play in cellular life. Based upon the oxidative phosphorylation defects in SMA, it follows that there is also evidence of altered ROS levels and oxidative stress in post-mortem patient material [34] and models of SMA [25, 26, 30, 35-37] (Table 2). Overall, the main finding has been of increased ROS and oxidative stress in SMA pathology, with any exceptions indicating that tissue/cell-type differences and the type of ROS examined are important. Relevantly, 4-hydroxynonenal (4-HNE) is generated primarily within mitochondria and is a marker of lipid peroxidation [38]. Although not exhaustively examined, 4-HNE is the only oxidative stress marker so far that has been associated with motor neuron pathology [27, 34, 35].

Mechanistically, SMN1 and SMN2 splicing [39-41] and activity of the SMN complex [42] can be regulated by ROS in oxidative stress-inducing conditions (Table 2). This suggests that increased ROS may be pathological in SMA through disruption of physiological ROS functions. Concurrently, oxidative stress induced by paraquat (a compound that increases mitochondrial ROS production [43]) reduces SMN protein levels [40, 41]. Therefore, along with reduced levels of SMN protein due to SMN mutation, increased mitochondrial ROS production may exacerbate and further reduce SMN protein levels. Whether reduced SMN levels in patients with SMA directly affects mitochondrial ROSgenerating processes as shown in cell studies [26, 36, 37], or whether mitochondrial ROS production and oxidative stress are increased due to an external factor (that may also 


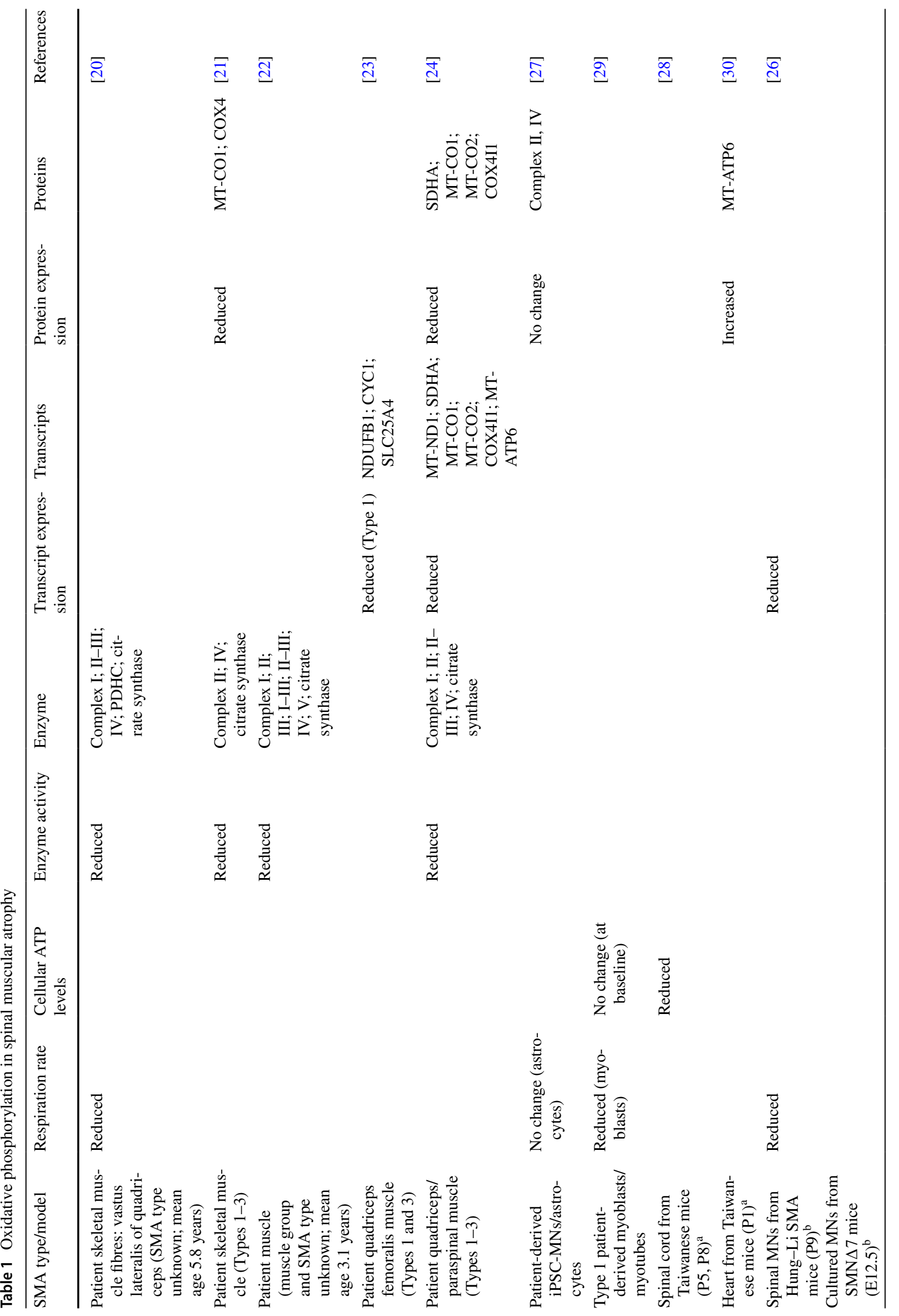




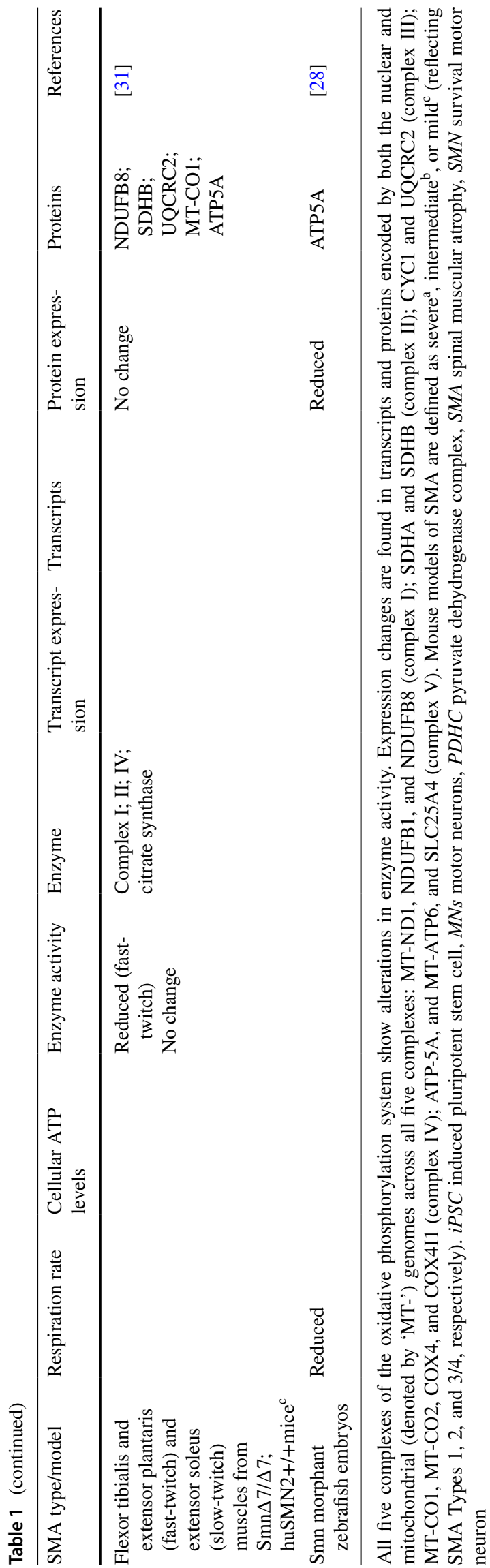

be SMA-related) is not yet clear. To address this question, it is pertinent to consider other aspects of SMA pathology that may be involved in producing an oxidative environment, specifically, the involvement of hypoxia.

Mitochondria are the main oxygen consumers of the cell and are critically dependent on oxygen availability for mediating their canonical function of oxidative phosphorylation. Consequently, they are implicitly involved in oxygen-sensing, and in turn, hypoxic cellular pathways, which interlinks with their role in intermediary metabolism [44]. Hypoxic changes are present in neuronal and non-neuronal tissues of SMA model mice at an early symptomatic time point [45, 46]. Like oxidative stress, hypoxia is mechanistically associated with SMN2 splicing, promoting exon 7 skipping through heterogeneous nuclear ribonucleoprotein (hnRNP)A1 (a negative regulatory splicing factor of SMN2 exon 7) in a severe mouse model of SMA [47]. Therapeutically, hnRNPA1 binding is blocked by Spinraza ${ }^{\circledR}$, which promotes exon 7 inclusion and production of full-length SMN protein [15]. Hypoxic pathways are also triggered at the molecular level by ROS production and hypoxia-inducible factors (HIFs), an oxygen-regulated family of transcription factors that modify glycolytic capacity and are reported sensors of mitochondrial health [48]. Under normal oxygen conditions, HIF $1 \alpha$ protein is rapidly degraded by ubiquitination processes involving the SMN-relevant proteins, ubiquitin-like modifier activating enzyme 1 (UBA1) $[49,50]$ and ubiquitin carboxyl-terminal hydrolase L1 [51, 52]. During hypoxia, increased mitochondrial ROS stabilises HIF1 $\alpha$ protein, leading to further activation of hypoxic signalling pathways. Due to functional changes in SMN-related ubiquitination, basal degradation of HIF1 $\alpha$ may be altered in SMA with increased mitochondrial ROS production further exacerbating this process. These potential hypoxic interactions between SMN and mitochondria have not been fully explored. Yet hypoxia offers a feasible environmental factor for influencing development of SMA, and unarguably, is a modifying influence on mitochondrial function.

\section{Mitochondrial metabolism}

Mitochondria are integral to metabolic pathways, both in terms of using end products as sources of electrons for the electron transport chain and providing ATP for further metabolic processes. Metabolism in turn is a critical link between molecular pathology and clinical care, since changes in nutritional care of patients can have direct impacts on metabolic function and vice versa. Metabolic dysfunction is an understudied area of research in SMA, but the few studies that have investigated this have found distinct perturbations in various kinds of metabolism across patient groups. Glucose, amino acids, and lipids can all be metabolised to provide substrates for ATP generation in mitochondria 
Table 2 Reactive oxygen species and oxidative stress pathology in spinal muscular atrophy

\begin{tabular}{|c|c|c|c|c|c|c|}
\hline SMA type/model & $\begin{array}{l}\text { ROS/Oxidative } \\
\text { stress marker }\end{array}$ & $\begin{array}{l}\text { ROS/Oxidative stress produc- } \\
\text { tion }\end{array}$ & SMN splicing & SMN complex & Rescue & References \\
\hline $\begin{array}{l}\text { Patient spinal cord and brain } \\
\text { tissue (Werdnig-Hoffman } \\
\text { disease; Type 1) }\end{array}$ & $\begin{array}{l}\text { 4-HNE } \\
\text { 8HOdG } \\
\text { 3-Nitrotyrosine }\end{array}$ & $\begin{array}{l}\text { Increased (MNs) } \\
\text { No change (MNs) } \\
\text { No change (MNs/brain) }\end{array}$ & & & & {$[34]$} \\
\hline $\begin{array}{l}\text { Type } 3 \text { patient-derived spinal } \\
\text { MNs }\end{array}$ & $\begin{array}{l}\text { MitoSOX } \\
\mathrm{H}_{2} \text { DCFDA } \\
\text { ATF-6 }\end{array}$ & $\begin{array}{l}\text { Increased } \\
\text { Increased } \\
\text { No change }\end{array}$ & & & Edaravone & {$[37]$} \\
\hline $\begin{array}{l}\text { Patient-derived iPSC-MNs/ } \\
\text { astrocytes }\end{array}$ & DHE & Reduced & & & & {$[27]$} \\
\hline $\begin{array}{l}\text { Paraquat-treated neuronal } \\
\text { and non-neuronal cell lines/ } \\
\text { patient-derived fibroblasts }\end{array}$ & & & Altered & & ASO (ISS-N1) & [40] \\
\hline $\begin{array}{l}\text { Stable SMN knockdown in } \\
\text { hESC-derived MNs }\end{array}$ & MitoSOX & Increased & & & & {$[36]$} \\
\hline $\begin{array}{l}\text { Paraquat-treated SH-SY5Y } \\
\text { human neuroblastoma cells }\end{array}$ & & & Altered & & & [39] \\
\hline $\begin{array}{l}\beta \text {-Lapachone-treated HeLa } \\
\text { cells }\end{array}$ & & & & $\begin{array}{l}\text { Modu- } \\
\text { lated (via } \\
\text { crosslinking) }\end{array}$ & & {$[42]$} \\
\hline $\begin{array}{l}\text { Smn siRNA knockdown in } \\
\text { NSC-34 cells }\end{array}$ & $\mathrm{H}_{2}$ DCFDA & Increased & & & & {$[25]$} \\
\hline $\begin{array}{l}\text { Cultured MNs from Smn } \Delta 7 \\
\text { mice }(\mathrm{E} 12.5)^{\mathrm{b}}\end{array}$ & Mito-roGFP & Increased & & & & [26] \\
\hline $\begin{array}{l}\text { Spinal cord from } \operatorname{Smn} \Delta 7 \text { mice } \\
(\mathrm{P} 4-8)^{\mathrm{b}}\end{array}$ & 8HOdG & No change & & & & {$[27]$} \\
\hline Heart from $\operatorname{Smn} \Delta 7$ mice $(\mathrm{P} 9)^{\mathrm{b}}$ & 3-Nitrotyrosine & Increased & & & Adenoviral-SMN & {$[35]$} \\
\hline $\begin{array}{l}\text { Paraquat-treated heterozygous } \\
\text { Taiwanese mice (6-8 weeks; } \\
\text { various tissues) }{ }^{\mathrm{a}}\end{array}$ & & & Altered & & & [41] \\
\hline
\end{tabular}

MitoSOX is a commercially available dye used to measure mitochondrial production of superoxide. Mito-roGFP measures the mitochondrial redox state using redox-sensitive GFP (roGFP) that is targeted to the mitochondrial matrix. Mouse models of SMA are defined as severe , intermediate $^{\mathrm{b}}$, or mild (reflecting SMA Types 1, 2, and 3/4, respectively). ASO (ISS-N1) antisense oligonucleotide targeting the SMN2 intronic splicing silencer N1, ATF-6 activating transcription factor 6, DHE dihydroethidium, H2DCFDA 2',7'-dichlorodihydrofluorescein diacetate, hESC human embryonic stem cell, 4-HNE 4-hydroxynonenal, $8 H O d G$ 8-oxo-2'-deoxyguanosine, MNs motor neurons, ROS reactive oxygen species, $S M A$ spinal muscular atrophy, $S M N$ survival motor neuron

[53]. Glucose metabolism is dysregulated in both patients and models of SMA. Mild and intermediate mouse models of SMA show glucose intolerance that increases with age as well as hyperglucagonemia, increased insulin sensitivity, and fasting hyperglycaemia [54, 55]. These metabolic phenotypes are accompanied by morphological changes in the pancreas, with pancreatic islet cells showing an increased proportion of glucagon-producing cells ( $\alpha$ cells) and a decreased proportion of insulin-producing cells ( $\beta$ cells). This change in islet cell composition was also found in patients with Type 1 SMA [54]. Patients with SMA are reported to have increased visceral fat mass, and children with Type 2 SMA and obesity are at higher risk for insulin resistance [56].

There is also evidence of amino acid metabolism dysregulation, again in both clinical and pre-clinical SMA research. Branched-chain amino acid (BCAA) pathways showed major changes in expression at early and symptomatic time points in a severe SMA mouse model, notably with reduced BCAA transaminase 2 (Bcat2) expression as a major catabolic enzyme of BCAAs [57]. This dysregulation of amino acid metabolism was also found in patients with Type 2 SMA [56]. Dyslipidemia and fatty deposits were found in the liver post-mortem in a cohort of patients with Type 2 SMA, which is mimicked in an intermediate mouse model [58]. This study also reported global dysregulation of fat and lipid metabolism. In the era of SMN-replacement therapies, these secondary characteristics of SMA are likely to become more pressing, both in terms of combinatorial therapy development and long-term disease management. At the cellular level, the ability to effectively switch between energetic fuels in response to fluctuating environmental conditions (such as during development or neuronal signalling) is dependent on the inherent metabolic flexibility of mitochondria, 
which is mediated by their ability to change shape $[59,60]$. Whether dysregulation in all three mitochondrial fuels in SMA pathology reflects loss of this adaptative ability in mitochondria remains to be determined.

\section{Apoptosis}

SMA pathology is primarily defined by motor neuron loss in the spinal cord, which reasonably may occur through apoptosis as a cell fate mechanism. Mitochondria are well-known as key activators of the intrinsic pathway of apoptosis [61], which involves a combination of pro- and anti-apoptotic proteins, including Bcl-2 family members, caspase family members, cytochrome $\mathrm{C}$, and $\mathrm{p} 53$. In support of a role for apoptosis in SMA, several studies have shown altered levels of these proteins in patients and models of SMA [62]. Further involvement of SMN protein at the molecular level can be inferred through SMN interactions with known apoptotic proteins. Recombinant SMN directly interacts with the anti-apoptopic and outer mitochondrial membrane (OMM) protein, $\mathrm{Bcl}-2$, to exert a synergistic effect against apoptosis in cell culture studies $[63,64]$. Although the physiological significance of this interaction has not been confirmed [65], there is ample evidence implicating Bcl-2 and other family members across the spectrum of SMA pathology in patient tissue [66], animal models [67], and cell culture models $[68,69]$. Another SMN interaction of interest to apoptosis is the pro-apoptotic protein, $\mathrm{p53}$, which in turn regulates the Bcl-2 family of proteins [70]. P53 is a transcription factor involved in cell stress and can both induce apoptosis (nuclear p53) and repress autophagy (cytosolic p53), which in part is dependent on p53 translocation to external (OMM) and internal (matrix) mitochondrial locations [71]. Nuclear p53 activity is selectively upregulated in disease-vulnerable spinal motor neurons in an intermediate mouse model of SMA [72], while direct interaction between SMN and nuclear p53 correlates with SMA disease severity in patient-derived fibroblasts [73]. Zinc-finger protein 1 (ZPR1) is another apoptosis-inducing protein and SMN interactor [74, 75]. ZPR1 expression levels are reduced in patients with SMA and may play a role in disease severity [76]. Corroboratively, ZPR1 was identified as a potential modifier of SMA pathology in mild and severe mouse models of SMA, with alternating effects on apoptosis that are dependent on ZPR1 expression levels [77]. Finally, the gene for neuronal apoptosis inhibitory protein (or NLR family apoptosis inhibitor protein; NAIP) is located within the genomic region of chromosome 5 that encompasses SMN1. NAIP is not the causative gene for SMA but NAIP mutations are suggested to modify disease severity in patients with SMA [78, 79], albeit their clinical significance is unclear [4]. Nevertheless, as NAIP is regulated by release of caspases 3 and 9 during apoptosis [80], it is reasonable that NAIP may play a modifying role in apoptosis of SMA motor neurons $[81,82]$. Aside from apoptosis, NAIP is most studied for its role in another mitochondrial pathway, that of activation of the innate immune system [83]. Thus, clarifying the mitochondrial role of Bcl-2, p53, ZPR1, and NAIP in apoptosis may shed further light on cell death mechanisms in SMN disease-vulnerable motor neurons.

\section{Mitochondrial trafficking}

Mitochondria constantly move around the cell to meet local metabolic and energetic demands, and are trafficked along the cellular cytoskeleton [84]. Cytoskeletal and trafficking processes have previously been implicated in SMA [17], suggesting that reasonably, SMN may also play a role in mitochondrial trafficking. Accordingly, smn- 1 was identified from a genetic screen in $C$. elegans to detect components of abnormal mitochondrial localisation [85]. Through interactions with actin-related protein 2 (ARX-2), smn- 1 was subsequently shown to influence mitochondrial localisation and distribution in muscle myofilaments. Patient-derived cell culture models of SMA show motor neuron-specific reductions in mitochondrial movement along axons [26, 86, 87] (Table 3). Reduced mitochondrial trafficking in SMA cell models may therefore reflect dissociation of SMN interactions between ARX-2 and actin filaments. Alternatively, tubulin-related mitochondrial trafficking is commonly implicated in other forms of SMA [88, 89] and motor neuron diseases [90], while intermediate filament aggregation disrupts mitochondrial movement in giant axonal neuropathy, a related neurological disorder [91]. Determining whether these cytoskeletal alterations in mitochondrial trafficking across disease classifications share SMN-related molecular disturbances may enable utilisation of shared modelling and therapeutic approaches.

\section{Mitochondrial quality control mechanisms}

\section{Mitochondrial dynamics}

Overlapping with a role in mitochondrial trafficking, the cytoskeleton is also involved in mitochondrial dynamics, which describes the intertwined fission and fusion capabilities of mitochondria [92]. Mitochondrial fission is a means of both mitochondrial replication and removal of damaged or dysfunctional mitochondria (i.e., mitophagy). Mitochondrial fusion enables the exchange of metabolites and other molecules (including mitochondrial DNA [mtDNA]) among mitochondria and leads to generation of the interconnected mitochondrial networks that are present in many cell types, such as neurons and muscle. Related to mitochondrial dynamics are mitochondrial biogenesis (generation of new mitochondria from pre-existing mitochondria) and 
Table 3 Mitochondrial abnormalities in spinal muscular atrophy

\begin{tabular}{|c|c|c|c|c|c|c|c|c|c|}
\hline $\begin{array}{l}\text { SMA type/ } \\
\text { model }\end{array}$ & Trafficking & Distribution & $\begin{array}{l}\text { mtDNA } \\
\text { content }\end{array}$ & Number & MMP & Morphology & Size & Rescue & References \\
\hline $\begin{array}{l}\text { Patient skel- } \\
\text { etal muscle } \\
\text { (Types } \\
1-3 \text { ) }\end{array}$ & & & Reduced & & & & & & {$[21]$} \\
\hline $\begin{array}{l}\text { Patient } \\
\text { quadriceps/ } \\
\text { paraspinal } \\
\text { muscle } \\
\text { (Types } \\
\text { 1-3) }\end{array}$ & & & $\begin{array}{l}\text { Reduced } \\
\quad \text { (corre- } \\
\text { lated with } \\
\text { disease } \\
\text { severity) }\end{array}$ & & & & & & {$[24]$} \\
\hline $\begin{array}{l}\text { Type 1 } \\
\text { patient- } \\
\text { derived } \\
\text { MNs from } \\
\text { iPSCs/ } \\
\text { hESCs }\end{array}$ & Reduced & & & Reduced & Reduced & & Reduced & $\begin{array}{l}N \text {-Acetyl- } \\
\text { cysteine } \\
\text { (antioxi- } \\
\text { dant) }\end{array}$ & {$[86]$} \\
\hline $\begin{array}{l}\text { Type } 1 \\
\text { patient- } \\
\text { derived } \\
\text { iPSC-MNs }\end{array}$ & Reduced & & & Reduced & & & Reduced & $\begin{array}{c}\text { Z-FA-FMK } \\
\text { (protease } \\
\text { inhibitor) }\end{array}$ & {$[87]$} \\
\hline $\begin{array}{l}\text { Type } 1 \\
\text { patient- } \\
\text { derived } \\
\text { myoblasts/ } \\
\text { myotubes }\end{array}$ & & & No change & & & & & & [29] \\
\hline $\begin{array}{l}\text { Smn siRNA } \\
\text { knockdown } \\
\text { in NSC-34 } \\
\text { cells }\end{array}$ & & & & & Increased & & & & {$[25]$} \\
\hline $\begin{array}{l}\text { Diaphragm } \\
\text { from } \\
\text { SMN } \Delta 7 \\
\text { mice } \\
(\mathrm{P} 14)^{\mathrm{b}}\end{array}$ & & & & $\begin{array}{l}\text { No change } \\
\text { (presynap- } \\
\text { tic) }\end{array}$ & & & $\begin{array}{l}\text { Reduced } \\
\text { (presynap- } \\
\text { tic) }\end{array}$ & & [95] \\
\hline $\begin{array}{l}\text { Tibialis ante- } \\
\text { rior muscle } \\
\text { from } \\
\text { SMN } \Delta 7 \\
\text { mice } \\
(\mathrm{P} 13)^{\mathrm{b}}\end{array}$ & & & & $\begin{array}{l}\text { Reduced } \\
\text { (presynap- } \\
\text { tic) }\end{array}$ & & $\begin{array}{l}\text { Normal } \\
\text { (presynap- } \\
\text { tic) }\end{array}$ & & & [97] \\
\hline $\begin{array}{l}\text { Tibialis ante- } \\
\text { rior muscle } \\
\text { from } \\
\text { SMN } \Delta 7 \\
\text { mice } \\
(\mathrm{P} 14)^{\mathrm{b}}\end{array}$ & & $\begin{array}{l}\text { Normal } \\
\text { (presynap- } \\
\text { tic) }\end{array}$ & & $\begin{array}{l}\text { Reduced } \\
\text { (presynap- } \\
\text { tic) }\end{array}$ & & & & & [96] \\
\hline $\begin{array}{l}\text { Cardiomyo- } \\
\text { cytes from } \\
\text { SMN } \Delta 7 \\
\text { mice } \\
(\mathrm{P} 14)^{\mathrm{b}}\end{array}$ & & & & & & $\begin{array}{l}\text { Degenera- } \\
\text { tive }\end{array}$ & Swollen & & [105] \\
\hline
\end{tabular}


Table 3 (continued)

\begin{tabular}{|c|c|c|c|c|c|c|c|c|c|}
\hline $\begin{array}{l}\text { SMA type/ } \\
\text { model }\end{array}$ & Trafficking & Distribution & $\begin{array}{l}\text { mtDNA } \\
\text { content }\end{array}$ & Number & MMP & Morphology & Size & Rescue & References \\
\hline $\begin{array}{l}\text { Spinal cord } \\
(\mathrm{P} 3, \mathrm{P} 9) \\
\text { and cul- } \\
\text { tured MNs } \\
(\mathrm{E} 12.5) \\
\text { from } \\
\text { SMN } \Delta 7 \\
\text { mice }^{\mathrm{b}}\end{array}$ & Reduced & & & & Reduced & $\begin{array}{l}\text { Fragmented/ } \\
\text { abnormal }\end{array}$ & Reduced & & [26] \\
\hline $\begin{array}{l}\text { Diaphragm/ } \\
\text { soleus from } \\
\text { Taiwanese } \\
\text { mice }(\mathrm{P} 4)^{\mathrm{a}}\end{array}$ & & & & & & $\begin{array}{l}\text { Fragmented/ } \\
\text { abnormal } \\
\text { (dia- } \\
\text { phragm) }\end{array}$ & $\begin{array}{l}\text { Swollen } \\
\text { (dia- } \\
\text { phragm) }\end{array}$ & $\begin{array}{l}S M N 2 \text { splic- } \\
\text { ing }\end{array}$ & {$[106]$} \\
\hline $\begin{array}{l}\text { Intercostal } \\
\text { muscles } \\
\text { from } \\
\text { Taiwanese } \\
\text { mice }(\mathrm{P} 4)^{\mathrm{a}}\end{array}$ & & & & & & Normal & Normal & & [108] \\
\hline $\begin{array}{l}\text { Cervical } \\
\text { spinal } \\
\text { cord from } \\
\text { Taiwanese } \\
\text { mice }(\mathrm{P} 3)^{\mathrm{a}}\end{array}$ & & & & & & Abnormal & Reduced & & [107] \\
\hline $\begin{array}{l}\text { Tibialis ante- } \\
\text { rior muscle } \\
\text { from } \\
\text { SMN2B } \\
\text { mice } \\
(\mathrm{P} 21)^{\mathrm{b}}\end{array}$ & & In vacuoles & & & & & & & [103] \\
\hline $\begin{array}{l}\text { C. elegans } \\
\text { smn-1 } \\
\text { mutant } \\
\text { body wall } \\
\text { muscle }\end{array}$ & & Abnormal & & & & Abnormal & & & [85] \\
\hline
\end{tabular}

Mouse models of SMA are defined as severe ${ }^{\mathrm{a}}$, intermediate ${ }^{\mathrm{b}}$, or mild (reflecting SMA Types 1, 2, and 3/4, respectively). hESCs human embryonic stem cells, iPSCs induced pluripotent stem cell, $M M P$ mitochondrial membrane potential, $M N s$ motor neurons, $m t D N A$ mitochondrial DNA, SMA spinal muscular atrophy, SMN survival motor neuron

mitophagy [93]. Taken together, these interrelated functions are viewed as quality control mechanisms to maintain a healthy mitochondrial population and optimise the energetic and metabolic output of the cell. Mitochondrial dynamics have already been implicated in the pathogenesis of neurodegenerative diseases [94], but have not yet become an area of active research for SMA. Despite this, there are indications that mitochondrial dynamics may be disrupted in smn-1 mutant worms, with disruption of the typical elongated mitochondrial network in the belly wall muscle [85]. This phenotype is supported by SMA cell models [26, 86, 87] showing reduced mitochondrial length, a concomitant increase in fragmentation, and reductions in fusion transcripts (Table 3). Overall, these changes are suggestive of impaired mitochondrial fusion in SMA.

\section{Mitochondrial biogenesis and mitophagy}

Mitochondrial biogenesis can be inferred through regulation of relevant transcriptional pathways, or more directly shown by the amount of mtDNA and/or number of mitochondria. There is evidence that all of these processes are altered in SMA pathology [21, 24, 26, 86, 87, 95-97]. In particular, reduced mtDNA content has been reported in patient muscle tissue $[21,24]$ that partially tracks with the clinical phenotype [23]. Reduced mitochondrial number and/or density are found in mouse [95-97] and cell culture [86, 87] models of SMA (Table 3). Importantly, there are muscle-specific differences that correlate with the disease phenotype: fewer mitochondria are detected in the disease-vulnerable tibialis anterior muscle of a severe SMA mouse model [96, 97], while no change was reported in the diaphragm at a similar postnatal stage [95]. Together these findings suggest there 
are less mitochondria in pathologically relevant cell types. However, it is not known how reduction of SMN protein and function is involved. Interestingly, there are clinical reports of mitochondrial phenocopies of SMA [98], defined as a disease that phenotypically resembles $\mathrm{SMN}$-associated SMA but without $S M N 1$ gene mutations. These phenocopies also show mtDNA depletion [99-102] and may prove useful for mechanistic understanding of the relationship between mtDNA content and SMA development.

Due to the reduced energetic capability of mitochondria in SMA, mitophagy should be activated as a cellular response to remove dysfunctional mitochondria. Vacuoles containing mitochondria were reported in an intermediate mouse model of SMA, and not in control mice [103], suggesting that mitophagy is activated in SMA. Mitophagy can be indirectly inferred by depolarisation of the mitochondrial membrane potential (MMP), which reflects the functional status and viability of mitochondria [104]. This has been examined in cell models of SMA [25, 26, 86] (Table 3), with stable knockdown of SMN levels associated with a depolarised MMP. This suggests that the mitochondrial population is functionally suboptimal and a mitophagic response should be induced. Further investigation of this process is needed to determine how altered SMN autophagic function may be involved, possibly preventing efficient removal of dysfunctional mitochondria.

\section{Mitochondrial morphology and size}

Mitochondrial morphology and size are remarkably heterogenous among cell types and are regulated in part by mitochondrial dynamics and the cytoskeleton. Together they impact upon the mitochondrion's energetic and metabolic output. Morphological abnormalities of mitochondria are evident in animal models of SMA [26, 85, 105-107] (Table 3), including alterations in cristae (the mitochondrial location of the ETC) at a pre-symptomatic stage of disease [26]. In addition, both larger [105, 106, 108] and smaller $[26,95,107]$ mitochondria have been reported in animal models of SMA (Table 3). Swollen or enlarged mitochondria may represent degenerative mechanisms acting downstream of reduced SMN protein levels. While smaller mitochondria may reflect a physiological phenotype of SMA pathology: indeed smaller mitochondria are associated with reduced SMN levels in cell culture models of SMA [86, 87].

\section{Mitochondrial import of proteins}

Due to the small number of proteins encoded by the mitochondrial genome (13 of $>1000$ mitochondrial proteins in humans [109]), mitochondria must import the rest of the proteins and other macromolecules needed for its function from the cytosol. Import occurs through protein complexes located within the outer and inner mitochondrial membranes, namely translocases of the outer membrane (TOM) and inner membrane (TIM) [110]. Mitochondrial import has not been directly investigated in SMA research, but there is tentative evidence that this process could be affected by SMA pathology. Reduced expression of mitochondrial import proteins has been shown in patient muscle biopsies [24] and patient-derived spinal motor neurons [111], albeit not in a mild mouse model of SMA [31]. Further, voltage-dependent anion-selective channel 1 (VDAC1) is an OMM import protein that interacts with stasimon, a protein involved in synaptic transmission and already implicated in SMN pathways [112]. VDAC1-stasimon interactions occur at specialised endoplasmic reticulum (ER)-mitochondria membrane contact sites [113]. Functionality of the VDAC1-stasimon interaction may be affected by reduced SMN levels, thereby implicating mitochondrial protein import in SMA pathology. Then rather curiously, recombinant SMN protein was shown to interact with TIM50 [114], a component of the TIM23 complex in the IMM that facilitates protein import from the TOM complex [115]. Within the TIM23 complex, TIM50 is the main receptor for inner membrane and matrixbound proteins and is closely linked to ETC assembly. The physiological relevance of this interaction has not been examined further. Although it may be expected that cytoplasmic SMN interacts with mitochondrial TIM50 before mitochondrial import, putative localisation of SMN at the IMM in rat spinal cord [116] hints at the possibility that SMN may directly interact with TIM50 in mitochondria. These potential SMN-mitochondrial connections in protein import need further corroboration to enable understanding of their functional significance.

\section{SMN localisation at mitochondria}

The prevailing viewpoint in the SMA field is that SMN does not localise to mitochondria $[25,117,118]$. However, re-evaluation of these studies suggests that there may be alternative interpretations of these conclusions. For example, although electron microscopy studies are technically challenging and their interpretation can be problematic, mitochondrial localisation of SMN in endogenous, diseasefree rat spinal cord at multiple developmental stages was reported by Pagliardini et al. [116]. SMN was most convincingly detected in close apposition to the OMM, a location corroborated by colocalisation of SMN and ARX-2 at mitochondria in C. elegans [85]. Surprisingly, SMN was also reported at the IMM. Additional support for mitochondrial localisation of SMN, particularly at the OMM, can be gleaned from protein interactions: either directly through putative SMN interactions with mitochondrial proteins 
(Bcl-2, p53, and TIM50) or indirectly via SMN-interacting proteins that also localise to mitochondria, namely, ARX2, stasimon, and neurocalcin delta (NCALD) [119], albeit most of these interactions have not been directly examined in this context. Transient localisation of SMN to mitochondria under certain cellular conditions and/or developmental stages seems likely. Given its function in transcription, translation, and proteostatic mechanisms, SMN is well suited to play a role in mitochondrial function. That mitochondria have recently been proposed as hubs of cellular proteostasis $[120,121]$ suggests this interaction could be reciprocal.

\section{A mitochondria-focused model of SMA disease and treatment}

\section{The role of mitochondria in SMA}

Mitochondrial dysfunction has long been reported in patients with SMA. Unsurprisingly, mitochondrial energetic and metabolic alterations are associated with reduction of SMN protein and SMA pathology (Fig. 2). By combining current research, a model of mitochondrial dysfunction in SMA can be postulated that incorporates overlapping SMN functions (Fig. 3). Alterations in mitochondrial quality control mechanisms will lead to less efficient removal and reduced production of new mitochondria. Linking mitochondrial biogenesis and mitophagy to SMNrelated function, $\beta$-catenin functions through the developmental Wnt signalling pathway [122] and was identified along with disrupted ubiquitin homeostasis as a driver of disease pathogenesis in SMA [50]. The cytosolic form of the mitochondrial phosphatase, PGAM family member 5 (PGAM5), was recently identified as a novel activator of $\mathrm{Wnt} / \beta$-catenin signalling, stimulating mitochondrial biogenesis and increasing mitochondrial number in response to mitochondrial stress [123]. In addition, the mitochondrial form of PGAM5 acts as a repressor of Wnt/ $\beta$-catenin signalling [124] and is involved in mitophagy [125, 126], again during times of mitochondrial stress. Opposing functions for related protein isoforms in the same signalling pathway suggests that $\mathrm{Wnt} / \beta$-catenin signalling, and in turn SMN, may be important to mitochondrial turnover.

Altered mitochondrial quality control and trafficking/ cytoskeletal defects may lead to changes in mitochondrial morphology, size, and subcellular distribution. Further mechanistic insights can again be inferred from known SMN-interacting proteins: HuD is an RNA-binding protein and SMN interactor [127], and together, both proteins influence mRNA transport [128]. Concurrently, HuD plays a role in mitochondrial dynamics, promoting mitochondrial fusion via transport of mitofusin 2 (MFN2) mRNA in

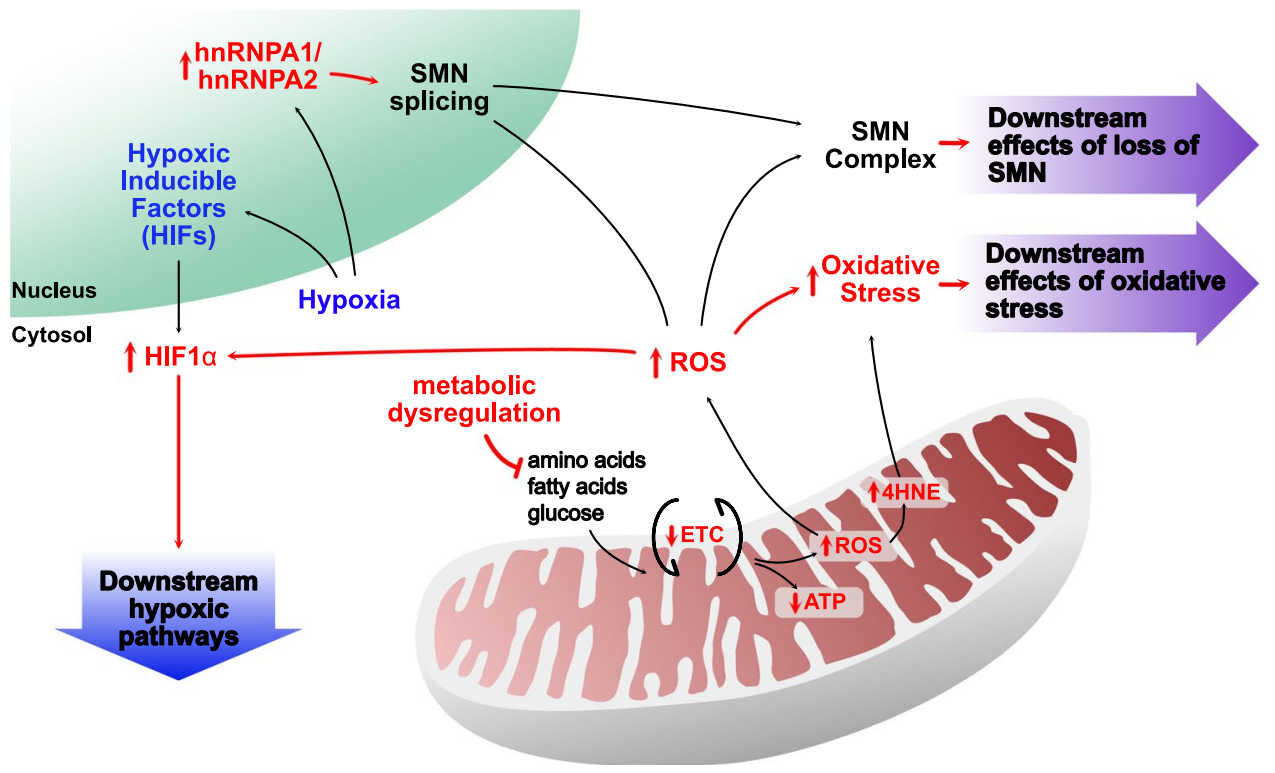

Fig. 2 Energetic and metabolic changes in spinal muscular atrophy. Decreased activity in the electron transport chain (ETC) is found in patients with spinal muscular atrophy (SMA) and across models of SMA. This leads to a decrease in ATP and increased reactive oxygen species (ROS) production. ETC dysfunction may be linked to the metabolic dysregulation evident in SMA. Increased ROS production can modulate survival motor neuron $(S M N)$ splicing as well as the SMN complex itself. Increased ROS causes oxidative stress, which is linked to an increase in 4-hydroxynoneal (4HNE) in SMA motor neurons. Hypoxia is another pathological process in SMA that also influences mitochondrial function, leading to an increase in production of hypoxic inducible factors (HIFs). In addition, HIF1 $\alpha$ is modulated by ROS through ubiquitination processes involving SMN-relevant proteins, leading to activation of downstream hypoxic pathways. Hypoxia is also associated with an increase in $S M N$ splicing factors, namely, heterogeneous nuclear ribonucleoprotein (hnRNP)-A1/A2 


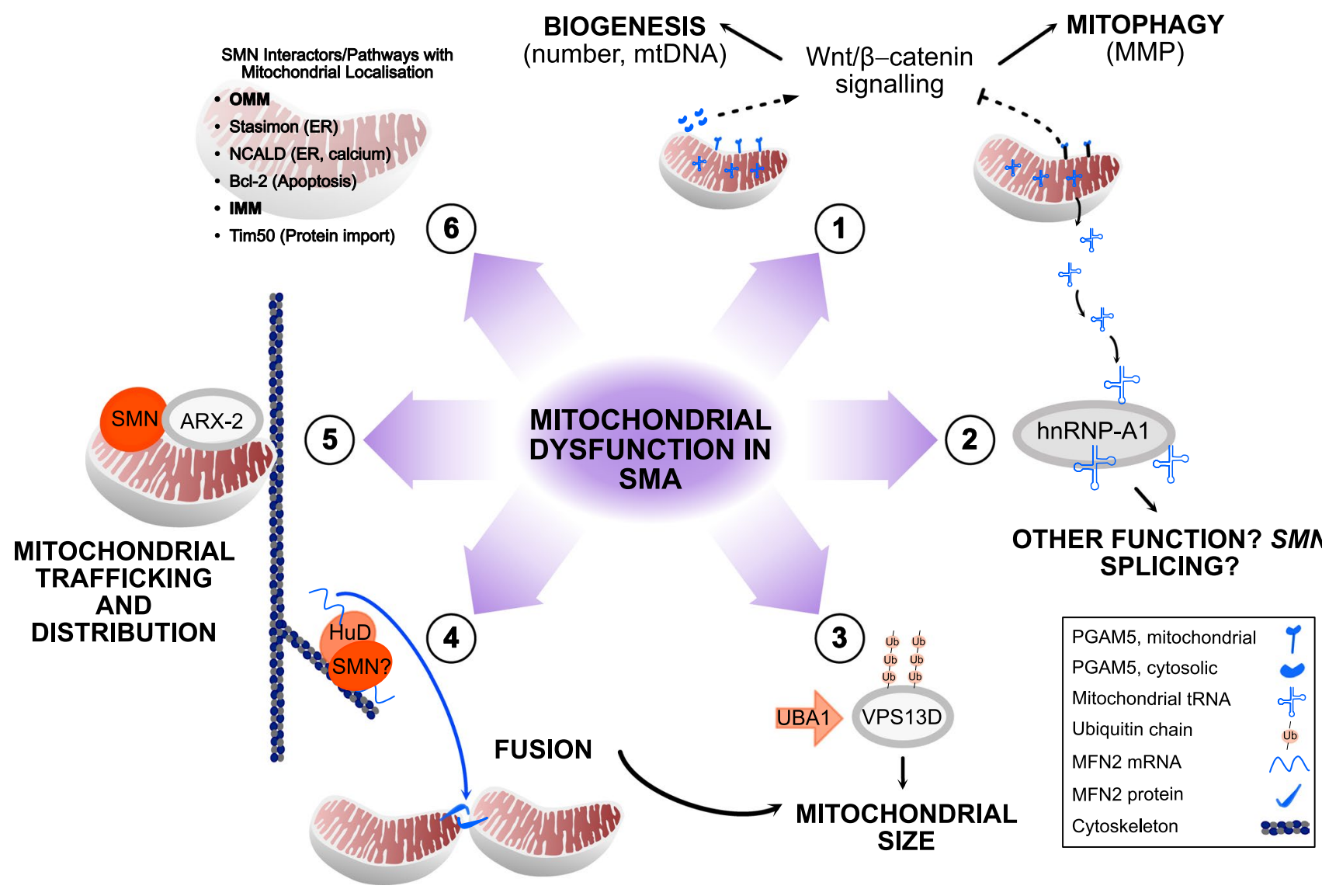

Fig. 3 Mitochondrial dysfunction in spinal muscular atrophy. 1. Following mitochondrial stress (e.g., hypoxia), mitochondrial PGAM family member 5 (PGAM5) inhibits Wnt// - catenin signalling, leading to mitophagy (indirectly determined by mitochondrial membrane potential [MMP]). In addition, cytosolic PGAM activates $\mathrm{Wnt} / \beta$ catenin signalling, leading to mitochondrial biogenesis (determined by mitochondrial number and mitochondrial DNA [mtDNA] production). This should ensure the removal of dysfunctional mitochondria and concurrent generation of new mitochondria to optimise the mitochondrial population during times of stress. The effect of survival motor neuron (SMN) in this mitochondrial stress pathway is not known but $W n t / \beta$-catenin signalling is a known driver of spinal muscular atrophy (SMA) pathology. 2. Mitochondrial transfer RNAs (tRNAs) are released from the mitochondrial matrix during mitochondrial stress, where they can interact with heterogeneous nuclear ribonucleoprotein (hnRNP)-A1 protein in the cytosol. The downstream effect of this interaction is not known but may involve mitonu- clear communication or mitophagy. Alternatively, hypoxia is already known to alter $S M N$ splicing via hnRNP proteins. 3. Ubiquitination of vacuolar protein sorting 13 homolog D (VPS13D) by a ubiquitin-like modifier activating enzyme 1 (UBA1)-mediated mechanism influences mitochondrial size and morphology through fission and fusion mechanisms. 4. HuD and SMN interact to transport mRNAs along the cytoskeleton. HuD has independently been shown to transport mRNA for the mitochondrial fusion protein, mitofusin 2 (MFN2), in pancreatic $\beta$ cells (a known site of dysfunction in SMA). 5. SMN colocalises with actin-related protein $2(\mathrm{ARX}-2)$ at mitochondria. Together both proteins are involved in mitochondrial trafficking and distribution. 6. Other SMN interactors (Bcl-2, Tim50) and pathways (stasimon, NCALD) have mitochondrial locations, albeit the direct effect of these proteins and downstream functions (in brackets) has not been determined. Dashed lines indicate pathways that are linked to mitochondrial stress mouse pancreatic $\beta$-cells [129], a known site of metabolic dysfunction in SMA. MFN2 is an OMM protein that is essential for mitochondrial fusion, and also a causative gene for Charcot-Marie-Tooth disease [94]. Whether reduction of SMN levels in SMA motor neurons can affect HuD-MFN2 transport is not known but warrants further investigation, especially given that mitochondrial fusion appears impaired in SMA models. SMN also plays a welldescribed role in ubiquitin homeostasis with the ubiquitin protein, UBA1, a known SMN interactor that is already implicated in SMA pathology [130]. Of relevance here, this SMN-related pathway was recently linked to mitochondrial size mechanisms in Drosophila [131]. Specifically, vacuolar protein sorting 13 homolog D (Vps13D) was identified from a screen investigating ubiquitin and UBA1-mediated autophagy mechanisms during intestinal development. Vps13D was subsequently shown to play a role in mediating mitochondrial size through fission and fusion mechanisms. Potential overlapping of SMN and UBA1/ubiquitin function in this mitochondrial size 
pathway provides another point at which mitochondrial and SMN functions may intersect.

Mitochondrial structure is known to beget its function. Consequently, abnormalities in mitochondrial morphology and dynamics may be reflected in patients with SMA by reduced energetic capability at the cellular level and dysregulated metabolic control at the systems-wide level. Apoptosis should be inevitable but imbalances in SMN-related proteins (e.g., p53, Bcl-2 family) may hinder this process. Hypoxia could be an early influence on mitochondrial dysfunction, leading to increased mitochondrial ROS production and oxidative stress. Recently, hnRNPA1 (the SMN2 splicing factor regulated by hypoxia) was shown to interact with a specific subset of mitochondrial transfer RNAs (tRNAs) [132] that were unexpectedly detected in the cytoplasm of HeLa cells. These proteins are typically found in the mitochondrial matrix where they are involved in translation of mitochondrial proteins. The biological significance of these cytosolic mitochondrial tRNAs is not yet apparent. They may be released following mitophagy and/or form part of regulatory crosstalk between mitochondria and the nucleus, possibly in times of mitochondrial stress. Further supporting this potential link between SMN2 splicing and mitochondrial function, another hnRNP protein, hnRNPA2, also binds to $S M N 2$ exon 7 and alters SMN2 protein levels [133]. HnRNPA2 is an established transcriptional co-activator involved in mediating the nuclear response to mitochondrial stress, at least in mouse skeletal muscle cells [134]. Theoretically then, $S M N 2$ splicing may be altered by hnRNP proteins in response to mitochondrial stress resulting from hypoxia. Notably, the pattern of mitochondrial dysfunction described is not unique to SMA and is akin to that reported for other neurodegenerative diseases [135, 136]. However, layered throughout this model is the potential for involvement of SMN function, not least its roles in ubiquitination and autophagy. Understanding this underlying mitochondrial deficit and how it intersects with SMN function could benefit patients with SMA at all stages of disease. In this regard, it is also pertinent to ask whether insight into SMA disease mechanisms can be obtained from present understanding of mitochondria.

Mitochondria are unequivocally bioenergetic and biosynthetic organelles, yet current research suggests that they should not be viewed solely as such. Indeed, mitochondria are increasingly recognised as signalling hubs either through generation of second messengers (e.g., ROS, $\mathrm{Ca}^{2+}$, ATP and other metabolites) or by acting as scaffolds for signalling complexes that form on the OMM [137-139]. Likely linked to their signalling capacity, is the emerging role that mitochondria play in cell fate pathways aside from apoptosis, including the cell cycle [140-142] and cellular differentiation [143, 144]. Mitochondrial involvement in these cell fate pathways highlights an interplay between ROS signalling and mitochondrial dynamics, both of which are altered in SMA pathology. Indeed, effective execution of these cell fate roles is likely to be affected by a functionally suboptimal mitochondrial population. Future consideration of SMN function in mitochondrial signalling and cell fate pathways may reveal a role for mitochondria in SMA that lies outside their canonical energetic role.

\section{Mitochondria-targeted therapies for SMA}

The primary treatment aimed at targeting mitochondria in SMA is Olesoxime, which made it through to phase III clinical trials. Olesoxime exerts its neuroprotective effects by modulating the mitochondrial permeability transition pore (an opening between the inner and outer mitochondrial membranes that is induced during pathology [145]), increasing cell survival in multiple in vitro and in vivo models [146]. Phase II clinical trials in non-ambulatory patients with Types 2/3 SMA showed a stabilisation, or even a slight increase, in motor function over the study period, whilst patients receiving a placebo showed a decline in motor function [147]. Unfortunately, Roche announced in 2018 that they were cancelling the phase III clinical trial due to difficulties in production and dosage as well as disappointing long-term results (https://www.treatsma.uk/wp-content/ uploads/2018/05/2018-05-30-Olesoxime-PG-update-May2018.pdf). However, since it is now clear that additional therapies are needed in combination with SMN replacement, cancelling Olesoxime clinical trials may come to be seen as premature and could still offer an option as a combinatorial ("SMN+") therapy.

Targeting metabolic pathways is a second strategy that could benefit mitochondrial function in SMA. For example, targeting the glycolytic enzyme, phosphoglycerate kinase 1 (PGK1), either genetically or pharmacologically, can improve motor neuron health in SMA models [28]. Transcriptionally PGK1 is induced by HIF1 $\alpha$ [148] and targeted to mitochondria following hypoxia [149], therefore the therapeutic benefit of PGK1 may involve hypoxic SMA mechanisms. Likewise, treatment with prednisolone (a corticosteroid that targets the transcription factor that modulates BCAA metabolism) or genetic overexpression of this transcription factor and therefore boosting of this metabolic pathway, doubled the lifespan of an intermediate mouse model of SMA. Glucocorticoids themselves are synthesised in mitochondria [150]. Potentially the therapeutic effects of prednisolone may also tap into mitochondrial-related glucocorticoid pathways.

More general metabolic approaches include changes to diet and exercise. In a mild SMA mouse model, forced exercise improved various markers of SMA pathology including fatiguability and motor neuron survival [151]. Further, a functional decrease in mitochondrial oxidative capacity 
was reversed by exercise intervention in a subset of muscle fibres in the same mouse model [31]. However, whether these results can be directly translated to human patients remains to be determined. A systematic review of evidence for and against exercise in patients with SMA was inconclusive due to heterogeneity of the patient groups and exercise performed [152]. This is obviously a difficult therapy to apply to patients with SMA due to their decreased motor abilities. A simpler target may be food intake. Targeting lipid dysregulation in SMA mice with a low-fat diet doubled their survival [58], whilst BCAA supplementation also improved SMA mouse model lifespan [57]. A recent systematic review described the lack of evidence for nutritional care in patients with SMA, an issue that is likely to become more pressing now that patients are living longer [153].

The early success of Olesoxime indicates that targeting mitochondria may still be an exciting avenue for future therapy development as a systemic, combinatorial option. Several therapies are being tested in other neurodegenerative diseases with mitochondrial dysfunction as a pathogenic hallmark, including metformin [154] and resveratrol [155] (see also recent reviews of mitochondrial therapies [156, 157]). Photobiomodulation is an alternative non-pharmacological approach that is gaining traction in neurodegenerative and brain injury fields $[158,159]$. Photobiomodulation uses light energy to modulate biological function with reported mitochondrial effects including increased mitochondrial respiration and mtDNA levels [160], altered mitochondrial dynamics [161], increased MMP and ATP production [162, 163], and redox effects [164]. Given the demographic of the patient group, this is obviously an attractive strategy since it is non-invasive, has minimal side effects, and enables targeted, localised treatment. Of relevance to SMA, positive effects of photobiomodulation have been reported on muscle fatigue in healthy subjects [165], while there are indications of efficacy in models of Alzheimer's disease, with improvements in both behavioural and molecular phenotypes [166]. Mitochondrial transplantation is another potential new avenue in mitochondrial therapies $[167,168]$, with the caveat that it is still very much at the experimental stage $[169,170]$. This approach is based on the premise of transplanting entire mitochondria to treat disease tissue [171]. It has recently been shown that neurons can take up mitochondria from neighbouring astrocytes in stroke models [172], and this mechanism may be boosted by administering mesenchymal stem cells [173]. Given that multiple mitochondrial functions are disrupted in SMA, targeting mitochondria at the organelle level is appealing. These therapeutic approaches are yet to be tested in SMA models but highlight future research opportunities.

\section{Conclusions}

As the genetic cause of SMA, SMN is imperative to disentangling the molecular phenotype of SMA and translating it back to the clinic. Yet determining the role of mitochondria in SMN function and SMA pathology may lead to clinical benefit that can complement SMN-replacement therapies. Mitochondria indisputably play an energetic role in motor neurons and muscle. Nevertheless, understanding of mitochondrial function has evolved considerably to show their more embedded role in wider cellular life. Intersection between SMN function and mitochondria can occur at multiple stages of SMA pathology. In turn, both SMN protein and mitochondria show pathological applicability that extends outside of motor neurons and muscle cells to affect every organ of the body. As SMA moves into a new era of treatment and disease progression, understanding the myriad roles of SMN protein and how they impact on generic and cell-type specific functions is ever more crucial for realisation of a cure for SMA.

Funding RJ holds a Daphne Jackson Trust Fellowship funded by Medical Research Scotland. HC is funded by the My Name' 5 Doddie foundation (Project Grant) and LML by a Medical Research Council (MRC) studentship (Precision Medicine PhD Studentship).

Availability of data and material Not applicable.

Code availability Not applicable.

\section{Declarations}

Conflict of interest/competing interest THG has served on SMA advisory boards for Roche.

Ethics approval (include appropriate approvals or waivers) Not applicable.

Consent to participate Not applicable.

Consent for publication Not applicable.

Open Access This article is licensed under a Creative Commons Attribution 4.0 International License, which permits use, sharing, adaptation, distribution and reproduction in any medium or format, as long as you give appropriate credit to the original author(s) and the source, provide a link to the Creative Commons licence, and indicate if changes were made. The images or other third party material in this article are included in the article's Creative Commons licence, unless indicated otherwise in a credit line to the material. If material is not included in the article's Creative Commons licence and your intended use is not permitted by statutory regulation or exceeds the permitted use, you will need to obtain permission directly from the copyright holder. To view a copy of this licence, visit http://creativecommons.org/licenses/by/4.0/. 


\section{References}

1. Lefebvre S, Bürglen L, Reboullet S et al (1995) Identification and characterization of a spinal muscular atrophy-determining gene. Cell 80:155-165. https://doi.org/10.1016/0092-8674(95) 90460-3

2. Lorson CL, Hahnen E, Androphy EJ, Wirth B (1999) A single nucleotide in the SMN gene regulates splicing and is responsible for spinal muscular atrophy. Proc Natl Acad Sci USA 96:63076311. https://doi.org/10.1073/pnas.96.11.6307

3. Monani UR, Lorson CL, Parsons DW et al (1999) A single nucleotide difference that alters splicing patterns distinguishes the SMA gene SMN1 from the copy gene SMN2. Hum Mol Genet 8:1177-1183. https://doi.org/10.1093/hmg/8.7.1177

4. Wadman RI, Jansen MD, Stam M et al (2020) Intragenic and structural variation in the SMN locus and clinical variability in spinal muscular atrophy. Brain Commun 2:fcaa075. https://doi. org/10.1093/braincomms/fcaa075

5. Talbot K, Tizzano EF (2017) The clinical landscape for SMA in a new therapeutic era. Gene Ther 24:529-533. https://doi.org/10. 1038 /gt.2017.52

6. Serra-Juhe C, Tizzano EF (2019) Perspectives in genetic counseling for spinal muscular atrophy in the new therapeutic era: early pre-symptomatic intervention and test in minors. Eur J Hum Genet 27:1774-1782. https://doi.org/10.1038/ s41431-019-0415-4

7. Finkel RS, Mercuri E, Darras BT et al (2017) Nusinersen versus sham control in infantile-onset spinal muscular atrophy. $\mathrm{N}$ Engl J Med 377:1723-1732. https://doi.org/10.1056/nejmoa1702752

8. Mendell JR, Al-Zaidy S, Shell R et al (2017) Single-dose genereplacement therapy for spinal muscular atrophy. N Engl J Med 377:1713-1722. https://doi.org/10.1056/nejmoa1706198

9. Ratni H, Ebeling M, Baird J et al (2018) Discovery of risdiplam, a selective survival of motor neuron-2 (SMN2) gene splicing modifier for the treatment of spinal muscular atrophy (SMA). J Med Chem 61:6501-6517. https://doi.org/10.1021/acs.jmedc hem. $8 \mathrm{~b} 00741$

10. Darrow JJ, Sharma M, Shroff M, Wagner AK (2020) Efficacy and costs of spinal muscular atrophy drugs. Sci Transl Med 12:eaay9648. https://doi.org/10.1126/scitranslmed.aay9648

11. Sansone VA, Pirola A, Albamonte E et al (2020) Respiratory needs in patients with type 1 spinal muscular atrophy treated with Nusinersen. J Pediatr 219:223-228.e4. https://doi.org/10.1016/j. jpeds.2019.12.047

12. Hully M, Barnerias C, Chabalier D et al (2020) Palliative care in SMA type 1: a prospective multicenter French study based on parents' reports. Front Pediatr 8:4. https://doi.org/10.3389/fped. 2020.00004

13. Hagenacker T, Wurster CD, Günther R et al (2020) Nusinersen in adults with $5 \mathrm{q}$ spinal muscular atrophy: a non-interventional, multicentre, observational cohort study. Lancet Neurol 19:317325. https://doi.org/10.1016/S1474-4422(20)30037-5

14. Hensel N, Kubinski S, Claus P (2020) The need for SMN-independent treatments of spinal muscular atrophy (SMA) to complement SMN-enhancing drugs. Front Neurol 11:45. https://doi.org/ 10.3389/fneur.2020.00045

15. Groen EJN, Talbot K, Gillingwater TH (2018) Advances in therapy for spinal muscular atrophy: promises and challenges. Nat Rev Neurol 14:214-224. https://doi.org/10.1038/nrneurol. 2018.4

16. Groen EJN, Perenthaler E, Courtney NL et al (2018) Temporal and tissue-specific variability of SMN protein levels in mouse models of spinal muscular atrophy. Hum Mol Genet 27:28512862. https://doi.org/10.1093/hmg/ddy195
17. Chaytow H, Huang YT, Gillingwater TH, Faller KME (2018) The role of survival motor neuron protein (SMN) in protein homeostasis. Cell Mol Life Sci 75:3877-3894. https://doi.org/10.1007/ s00018-018-2849-1

18. Edens BM, Ajroud-Driss S, Ma L, Ma YC (2015) Molecular mechanisms and animal models of spinal muscular atrophy. Biochim Biophys Acta Mol Basis Dis 1852:685-692. https://doi.org/ 10.1016/j.bbadis.2014.07.024

19. Sleigh JN, Gillingwater TH, Talbot K (2011) The contribution of mouse models to understanding the pathogenesis of spinal muscular atrophy. Dis Model Mech 4:457-467. https://doi.org/ 10.1242/dmm.007245

20. Sperl W, Skladal D, Gnaiger E et al (1997) High resolution respirometry of permeabilized skeletal muscle fibers in the diagnosis of neuromuscular disorders. Mol Cell Biochem 174:71-78. https://doi.org/10.1023/A:1006880529195

21. Berger A, Mayr JA, Meierhofer D et al (2003) Severe depletion of mitochondrial DNA in spinal muscular atrophy. Acta Neuropathol 105:245-251. https://doi.org/10.1007/s00401-002-0638-1

22. Jongpiputvanich S, Sueblinvong T, Norapucsunton T (2005) Mitochondrial respiratory chain dysfunction in various neuromuscular diseases. J Clin Neurosci 12:426-428. https://doi.org/ 10.1016/j.jocn.2004.06.014

23. Millino C, Fanin M, Vettori A et al (2009) Different atrophyhypertrophy transcription pathways in muscles affected by severe and mild spinal muscular atrophy. BMC Med 7:14. https://doi. org/10.1186/1741-7015-7-14

24. Ripolone M, Ronchi D, Violano R et al (2015) Impaired muscle mitochondrial biogenesis and myogenesis in spinal muscular atrophy. JAMA Neurol 72:666-675. https://doi.org/10.1001/ jamaneurol.2015.0178

25. Acsadi G, Lee I, Li X et al (2009) Mitochondrial dysfunction in a neural cell model of spinal muscular atrophy. J Neurosci Res 87:2748-2756. https://doi.org/10.1002/jnr.22106

26. Miller N, Shi H, Zelikovich AS, Ma YC (2015) Motor neuron mitochondrial dysfunction in spinal muscular atrophy. Hum Mol Genet 25:3395-3406. https://doi.org/10.1093/hmg/ddw262

27. Patitucci TN, Ebert AD (2016) SMN deficiency does not induce oxidative stress in SMA iPSC-derived astrocytes or motor neurons. Hum Mol Genet 25:514-523. https://doi.org/10.1093/hmg/ $\operatorname{ddv} 489$

28. Boyd PJ, Tu WY, Shorrock HK et al (2017) Bioenergetic status modulates motor neuron vulnerability and pathogenesis in a zebrafish model of spinal muscular atrophy. PLoS Genet 13:e1006744. https://doi.org/10.1371/journal.pgen.1006744

29. Hellbach N, Peterson S, Haehnke D et al (2018) Impaired myogenic development, differentiation and function in hESC-derived SMA myoblasts and myotubes. PLoS ONE 13:e1006744. https:// doi.org/10.1371/journal.pone.0205589

30. Maxwell GK, Szunyogova E, Shorrock HK et al (2018) Developmental and degenerative cardiac defects in the Taiwanese mouse model of severe spinal muscular atrophy. J Anat 232:965-978. https://doi.org/10.1111/joa.12793

31. Houdebine L, D'Amico D, Bastin J et al (2019) Low-intensity running and high-intensity swimming exercises differentially improve energy metabolism in mice with mild spinal muscular atrophy. Front Physiol 10:1258. https://doi.org/10.3389/fphys. 2019.01258

32. Montes J, Garber CE, Kramer SS et al (2015) Single-blind, randomized, controlled clinical trial of exercise in ambulatory spinal muscular atrophy: why are the results negative? J Neuromuscul Dis 2:463-470. https://doi.org/10.3233/JND-150101

33. Sies H, Jones DP (2020) Reactive oxygen species (ROS) as pleiotropic physiological signalling agents. Nat Rev Mol Cell Biol 21:363-383. https://doi.org/10.1038/s41580-020-0230-3 
34. Hayashi M, Araki S, Arai N et al (2002) Oxidative stress and disturbed glutamate transport in spinal muscular atrophy. Brain Dev 24:770-775. https://doi.org/10.1016/S0387-7604(02)00103-1

35. Shababi M, Habibi J, Ma L et al (2012) Partial restoration of cardio-vascular defects in a rescued severe model of spinal muscular atrophy. J Mol Cell Cardiol 52:1074-1082. https://doi.org/ 10.1016/j.yjmcc.2012.01.005

36. Wang ZB, Zhang X, Li XJ (2013) Recapitulation of spinal motor neuron-specific disease phenotypes in a human cell model of spinal muscular atrophy. Cell Res 23:378-393. https://doi.org/ 10.1038/cr.2012.166

37. Ando S, Funato M, Ohuchi K et al (2017) Edaravone is a candidate agent for spinal muscular atrophy: In vitro analysis using a human induced pluripotent stem cells-derived disease model. Eur J Pharmacol 814:161-168. https://doi.org/10.1016/j.ejphar. 2017.08.005

38. Zhong H, Yin H (2015) Role of lipid peroxidation derived 4-hydroxynonenal (4-HNE) in cancer: focusing on mitochondria. Redox Biol 4:193-199. https://doi.org/10.1016/j.redox.2014.12. 011

39. Maracchioni A, Totaro A, Angelini DF et al (2007) Mitochondrial damage modulates alternative splicing in neuronal cells: implications for neurodegeneration. J Neurochem 100:142-153. https://doi.org/10.1111/j.1471-4159.2006.04204.x

40. Singh NN, Seo J, Rahn SJ, Singh RN (2012) A multi-exonskipping detection assay reveals surprising diversity of splice isoforms of spinal muscular atrophy genes. PLoS ONE 7:e49595. https://doi.org/10.1371/journal.pone.0049595

41. Seo J, Singh NN, Ottesen EW et al (2016) Oxidative stress triggers body-wide skipping of multiple exons of the spinal muscular atrophy gene. PLoS ONE 11:e0154390. https://doi.org/10.1371/ journal.pone. 0154390

42. Wan L, Ottinger E, Cho S, Dreyfuss G (2008) Inactivation of the SMN complex by oxidative stress. Mol Cell 31:244-254. https:// doi.org/10.1016/j.molcel.2008.06.004

43. Castello PR, Drechsel DA, Patel M (2007) Mitochondria are a major source of paraquat-induced reactive oxygen species production in the brain. J Biol Chem 282:14186-14193. https://doi. org/10.1074/jbc.M700827200

44. Fuhrmann DC, Brüne B (2017) Mitochondrial composition and function under the control of hypoxia. Redox Biol 12:208-215. https://doi.org/10.1016/j.redox.2017.02.012

45. Somers E, Lees RD, Hoban K et al (2016) Vascular defects and spinal cord hypoxia in spinal muscular atrophy. Ann Neurol 79:217-230. https://doi.org/10.1002/ana.24549

46. Hernandez-Gerez E, Dall'Angelo S, Collinson JM et al (2020) Widespread tissue hypoxia dysregulates cell and metabolic pathways in SMA. Ann Clin Transl Neurol 7:1580-1593. https://doi. org/10.1002/acn3.51134

47. Bebee TW, Dominguez CE, Samadzadeh-tarighat S et al (2012) Hypoxia is a modifier of SMN2 splicing and disease severity in a severe SMA mouse model. Hum Mol Genet 21:4301-4313. https://doi.org/10.1093/hmg/dds263

48. Thomas LW, Ashcroft M (2019) Exploring the molecular interface between hypoxia-inducible factor signalling and mitochondria. Cell Mol Life Sci 76:1759-1777. https://doi.org/10.1007/ s00018-019-03039-y

49. Kamura T, Sato S, Iwai K et al (2000) Activation of HIF1 ubiquitination by a reconstituted von Hippel-Lindau (VHL) tumor suppressor complex. Proc Natl Acad Sci USA 35:e142. https:// doi.org/10.1093/nar/gkm932

50. Wishart TM, Mutsaers CA, Riessland M et al (2014) Dysregulation of ubiquitin homeostasis and $\beta$-catenin signaling promote spinal muscular atrophy. J Clin Investig 124:1821-1834. https:// doi.org/10.1172/JCI71318
51. Goto Y, Zeng L, Yeom CJ et al (2015) UCHL1 provides diagnostic and antimetastatic strategies due to its deubiquitinating effect on HIF-1 $\alpha$. Nat Commun 6:6153. https://doi.org/10.1038/ncomm s7153

52. Hsu SH, Lai MC, Er TK et al (2010) Ubiquitin carboxyl-terminal hydrolase L1 (UCHL1) regulates the level of SMN expression through ubiquitination in primary spinal muscular atrophy fibroblasts. Clin Chim Acta 411:1920-1928. https://doi.org/10.1016/j. cca.2010.07.035

53. Spinelli JB, Haigis MC (2018) The multifaceted contributions of mitochondria to cellular metabolism. Nat Cell Biol 20:745-754. https://doi.org/10.1038/s41556-018-0124-1

54. Bowerman M, Swoboda KJ, Michalski JP et al (2012) Glucose metabolism and pancreatic defects in spinal muscular atrophy. Ann Neurol 72:256-268. https://doi.org/10.1002/ana.23582

55. Bowerman M, Michalski JP, Beauvais A et al (2014) Defects in pancreatic development and glucose metabolism in SMNdepleted mice independent of canonical spinal muscular atrophy neuromuscular pathology. Hum Mol Genet 23:3432-3444. https://doi.org/10.1093/hmg/ddu052

56. Davis RH, Miller EA, Zhang RZ, Swoboda KJ (2015) Responses to fasting and glucose loading in a cohort of well children with spinal muscular atrophy type II. J Pediatr 167:1362-1368.e1. https://doi.org/10.1016/j.jpeds.2015.09.023

57. Walter LM, Deguise MO, Meijboom KE et al (2018) Interventions targeting glucocorticoid-Krüppel-like factor 15-branchedchain amino acid signalling improve disease phenotypes in spinal muscular atrophy mice. EBioMedicine 31:226-242. https://doi. org/10.1016/j.ebiom.2018.04.024

58. Deguise MO, Baranello G, Mastella C et al (2019) Abnormal fatty acid metabolism is a core component of spinal muscular atrophy. Ann Clin Transl Neurol 6:1519-1532. https://doi.org/ $10.1002 / \operatorname{acn} 3.50855$

59. Muoio DM (2014) Metabolic inflexibility: when mitochondrial indecision leads to metabolic gridlock. Cell 159:1253-1262. https://doi.org/10.1016/j.cell.2014.11.034

60. Smith RL, Soeters MR, Wüst RCI, Houtkooper RH (2018) Metabolic flexibility as an adaptation to energy resources and requirements in health and disease. Endocr Rev 39:489-517. https://doi. org/10.1210/er.2017-00211

61. Xiong S, Mu T, Wang G, Jiang X (2014) Mitochondria-mediated apoptosis in mammals. Protein Cell 5:737-749. https://doi.org/ 10.1007/s13238-014-0089-1

62. Anderton RS, Meloni BP, Mastaglia FL, Boulos S (2013) Spinal muscular atrophy and the anti-apoptotic role of survival of motor neuron (SMN) protein. Mol Neurobiol 47:821-832. https://doi. org/10.1007/s12035-013-8399-5

63. Iwahashi H, Eguchi Y, Yasuhara N et al (1997) Synergistic antiapoptotic activity between Bcl-2 and SMN implicated in spinal muscular atrophy. Nature 390:413-417. https://doi.org/10.1038/ 37144

64. Sato K, Eguchi Y, Kodama TS, Tsujimoto Y (2000) Regions essential for the interaction between Bcl-2 and SMN, the spinal muscular atrophy disease gene product. Cell Death Differ 7:374-383. https://doi.org/10.1038/sj.cdd.4400660

65. Coovert DD, Le TT, Morris GE et al (2000) Does the survival motor neuron protein (SMN) interact with Bcl-2? J Med Genet 37:536-539

66. Simic G, Seso-Simic D, Lucassen PJ et al (2000) Ultrastructural analysis and TUNEL demonstrate motor neuron apoptosis in Werdnig-Hoffmann disease. J Neuropathol Exp Neurol 59:398-407. https://doi.org/10.1093/jnen/59.5.398

67. Piras A, Schiaffino L, Boido M et al (2017) Inhibition of autophagy delays motoneuron degeneration and extends lifespan in a mouse model of spinal muscular atrophy. Cell Death Dis 8:3223-3238. https://doi.org/10.1038/s41419-017-0086-4 
68. Tsai LK, Tsai MS, Ting CH, Li H (2008) Multiple therapeutic effects of valproic acid in spinal muscular atrophy model mice. J Mol Med 86:1243-1254. https://doi.org/10.1007/ s00109-008-0388-1

69. Garcera A, Mincheva S, Gou-Fabregas M et al (2011) A new model to study spinal muscular atrophy: neurite degeneration and cell death is counteracted by BCL-XL overexpression in motoneurons. Neurobiol Dis 42:415-426. https://doi.org/10.1016/j. nbd.2011.02.003

70. Green DR, Kroemer G (2009) Cytoplasmic functions of the tumour suppressor p53. Nature 458:1127-1130. https://doi.org/ 10.1038 /nature07986

71. Mariño G, Niso-Santano M, Baehrecke EH, Kroemer G (2014) Self-consumption: the interplay of autophagy and apoptosis. Nat Rev Mol Cell Biol 15:81-94. https://doi.org/10.1038/nrm3735

72. Simon CM, Dai Y, Van Alstyne M et al (2017) Converging mechanisms of $\mathrm{p} 53$ activation drive motor neuron degeneration in spinal muscular atrophy. Cell Rep 21:3767-3780. https://doi. org/10.1016/j.celrep.2017.12.003

73. Young PJ, Day PM, Zhou J et al (2002) A direct interaction between the survival motor neuron protein and p53 and its relationship to spinal muscular atrophy. J Biol Chem 277:2852-2859. https://doi.org/10.1074/jbc.M108769200

74. Gangwani L, Mikrut M, Theroux S et al (2001) Spinal muscular atrophy disrupts the interaction of ZPR1 with the SMN protein. Nat Cell Biol 3:376-383. https://doi.org/10.1038/35070059

75. Gangwani L, Flavell RA, Davis RJ (2005) ZPR1 is essential for survival and is required for localization of the survival motor neurons (SMN) protein to Cajal bodies. Mol Cell Biol 25:27442756. https://doi.org/10.1128/mcb.25.7.2744-2756.2005

76. Helmken C, Hofmann Y, Schoenen F et al (2003) Evidence for a modifying pathway in SMA discordant families: reduced SMN level decreases the amount of its interacting partners and Htra2-beta1. Hum Genet 114:11-21. https://doi.org/10.1007/ s00439-003-1025-2

77. Ahmad S, Wang Y, Shaik GM et al (2012) The zinc finger protein ZPR1 is a potential modifier of spinal muscular atrophy. Hum Mol Genet 21:2745-2758. https://doi.org/10.1093/hmg/dds102

78. Roy N, Mahadevan MS, McLean M et al (1995) The gene for neuronal apoptosis inhibitory protein is partially deleted in individuals with spinal muscular atrophy. Cell 80:167-178. https:// doi.org/10.1016/0092-8674(95)90461-1

79. Soler-Botija C, Ferrer I, Alvarez JL et al (2003) Downregulation of Bcl-2 proteins in type I spinal muscular atrophy motor neurons during fetal development. J Neuropathol Exp Neurol 62:420-426. https://doi.org/10.1093/jnen/62.4.420

80. Liston P, Fong WG, Korneluk RG (2003) The inhibitors of apoptosis: there is more to life than Bcl2. Oncogene 22:8568-8580. https://doi.org/10.1038/sj.onc.1207101

81. Tsai CH, Jong YJ, Hu CJ et al (2001) Molecular analysis of SMN, NAIP and P44 genes of SMA patients and their families. J Neurol Sci 190:35-40. https://doi.org/10.1016/S0022-510X(01)00574-3

82. Watihayati MS, Fatemeh H, Marini M et al (2009) Combination of SMN2 copy number and NAIP deletion predicts disease severity in spinal muscular atrophy. Brain Dev 31:42-45. https://doi. org/10.1016/j.braindev.2008.08.012

83. Kofoed EM, Vance RE (2012) NAIPs: building an innate immune barrier against bacterial pathogens: NAIPs function as sensors that initiate innate immunity by detection of bacterial proteins in the host cell cytosol. BioEssays 34:589-598. https://doi.org/ 10.1002/bies.201200013

84. Cardanho-Ramos C, Faria-Pereira A, Morais VA (2020) Orchestrating mitochondria in neurons: cytoskeleton as the conductor. Cytoskeleton 77:65-75. https://doi.org/10.1002/cm.21585

85. Schultz J, Lee SJ, Cole T et al (2017) The secreted MSP domain of C. elegans VAPB homolog VPR-1 patterns the adult striated muscle mitochondrial reticulum via SMN-1. J Cell Sci 130:2175-2186. https://doi.org/10.1242/dev.152025

86. Xu CC, Denton KR, Wang ZB et al (2016) Abnormal mitochondrial transport and morphology as early pathological changes in human models of spinal muscular atrophy. DMM Dis Model Mech 9:39-49. https://doi.org/10.1242/dmm.021766

87. Wang Y, Xu C, Ma L et al (2019) Drug screening with human SMN2 reporter identifies SMN protein stabilizers to correct SMA pathology. Life Sci Alliance 2:e201800268. https://doi. org/10.26508/lsa.201800268

88. Hoang HT, Schlager MA, Carter AP, Bullock SL (2017) DYNC1H1 mutations associated with neurological diseases compromise processivity of dynein-dynactin-cargo adaptor complexes. Proc Natl Acad Sci USA 114:E1597-E1606. https://doi. org/10.1073/pnas.1620141114

89. Carrera LAM, Gabriel E, Donohoe CD et al (2018) Novel insights into SMALED2: BICD2 mutations increase microtubule stability and cause defects in axonal and NMJ development. Hum Mol Genet 27:1772-1784. https://doi.org/10.1093/hmg/ddy086

90. Lipka J, Kuijpers M, Jaworski J, Hoogenraad CC (2013) Mutations in cytoplasmic dynein and its regulators cause malformations of cortical development and neurodegenerative diseases. Biochem Soc Trans 41:1605-1612. https://doi.org/10.1042/ BST20130188

91. Israeli E, Dryanovski DI, Schumacker PT et al (2016) Intermediate filament aggregates cause mitochondrial dysmotility and increase energy demands in giant axonal neuropathy. Hum Mol Genet 25:2143-2157. https://doi.org/10.1093/hmg/ddw081

92. Detmer SA, Chan DC (2007) Functions and dysfunctions of mitochondrial dynamics. Nat Rev Mol Cell Biol 8:870-879. https://doi.org/10.1038/nrm2275

93. Picca A, Mankowski RT, Burman JL et al (2018) Mitochondrial quality control mechanisms as molecular targets in cardiac ageing. Nat Rev Cardiol 15:543-554. https://doi.org/10.1038/ s41569-018-0059-Z

94. Burté F, Carelli V, Chinnery PF, Yu-Wai-Man P (2015) Disturbed mitochondrial dynamics and neurodegenerative disorders. Nat Rev Neurol 11:11-24. https://doi.org/10.1038/nrneu rol.2014.228

95. Kariya S, Park GH, Maeno-Hikichi Y et al (2008) Reduced SMN protein impairs maturation of the neuromuscular junctions in mouse models of spinal muscular atrophy. Hum Mol Genet 17:2552-2569. https://doi.org/10.1093/hmg/ddn156

96. Torres-Benito L, Neher MF, Cano R et al (2011) SMN requirement for synaptic vesicle, active zone and microtubule postnatal organization in motor nerve terminals. PLoS Os 6:e26164. https://doi.org/10.1371/journal.pone.0026164

97. Kong L, Wang X, Choe DW et al (2009) Impaired synaptic vesicle release and immaturity of neuromuscular junctions in spinal muscular atrophy mice. J Neurosci 29:842-851. https://doi.org/ 10.1523/JNEUROSCI.4434-08.2009

98. Mancuso M, Filosto M, Hirano M, DiMauro S (2003) Spinal muscular atrophy and mitochondrial DNA depletion. Response to Berber et al. (2003) Acta Neuropathol 105:245-251. Acta Neuropathol 105:621-622. https://doi.org/10.1007/s00401-003-0699-9

99. Pons R, Andreetta F, Wang CH et al (1996) Mitochondrial myopathy simulating spinal muscular atrophy. Pediatr Neurol 15:153-158. https://doi.org/10.1016/0887-8994(96)00118-x

100. Rubio-Gozalbo M, Smeitink J, Ruitenbeek W et al (1999) Spinal muscular atrophy-like picture, cardiomyopathy, and cytochrome c oxidase deficiency. Neurology 52:383-386. https://doi.org/10. $1212 / \mathrm{wnl} .52 .2 .383$

101. Mancuso M, Salviati L, Sacconi S et al (2002) Mitochondrial DNA depletion mutations in thymidine kinase gene with myopathy and SMA. Neurology 59:1197-1202. https://doi.org/10. 1212/01.wnl.0000028689.93049.9a 
102. Boczonadi V, King MS, Smith AC et al (2018) Mitochondrial oxodicarboxylate carrier deficiency is associated with mitochondrial DNA depletion and spinal muscular atrophy-like disease. Genet Med 20:1224-1235. https://doi.org/10.1038/gim.2017.251

103. Deguise MO, Boyer JG, McFall ER et al (2016) Differential induction of muscle atrophy pathways in two mouse models of spinal muscular atrophy. Sci Rep 6:28846. https://doi.org/10. 1038/srep28846

104. Zorova LD, Popkov VA, Plotnikov EY et al (2018) Mitochondrial membrane potential. Anal Biochem 552:50-59. https://doi.org/ 10.1016/j.ab.2017.07.009

105. Bevan AK, Hutchinson KR, Foust KD et al (2010) Early heart failure in the SMN $\Delta 7$ model of spinal muscular atrophy and correction by postnatal scAAV9-SMN delivery. Hum Mol Genet 19:3895-3905. https://doi.org/10.1093/hmg/ddq300

106. Voigt T, Meyer K, Baum O, Schümperli D (2010) Ultrastructural changes in diaphragm neuromuscular junctions in a severe mouse model for Spinal Muscular Atrophy and their prevention by bifunctional U7 snRNA correcting SMN2 splicing. Neuromuscul Disord 20:744-752. https://doi.org/10.1016/j.nmd.2010. 06.010

107. Neve A, Trüb J, Saxena S, Schümperli D (2016) Central and peripheral defects in motor units of the diaphragm of spinal muscular atrophy mice. Mol Cell Neurosci 70:30-41. https://doi.org/ 10.1016/j.mcn.2015.11.007

108. Voigt T, Neve A, Schümperli D (2014) The craniosacral progression of muscle development influences the emergence of neuromuscular junction alterations in a severe murine model for spinal muscular atrophy. Neuropathol Appl Neurobiol 40:416-434. https://doi.org/10.1111/nan.12064

109. Calvo SE, Mootha VK (2010) The mitochondrial proteome and human disease. Annu Rev Genom Hum Genet 11:25-44. https:// doi.org/10.1146/annurev-genom-082509-141720

110. Chacinska A, Koehler CM, Milenkovic D et al (2009) Importing mitochondrial proteins: machineries and mechanisms. Cell 138:628-644. https://doi.org/10.1016/j.cell.2009.08.005

111. Ando S, Funato M, Ohuchi K et al (2019) The protective effects of Levetiracetam on a human iPSCs-derived spinal muscular atrophy model. Neurochem Res 44:1773-1779. https://doi.org/ 10.1007/s11064-019-02814-4

112. Lotti F, Imlach WL, Saieva L et al (2012) An SMN-dependent U12 splicing event essential for motor circuit function. Cell 151:440-454. https://doi.org/10.1016/j.cell.2012.09.012

113. Van Alstyne M, Lotti F, Dal Mas A et al (2018) Stasimon/ Tmem $41 \mathrm{~b}$ localizes to mitochondria-associated ER membranes and is essential for mouse embryonic development. Biochem Biophys Res Commun 506:463-470. https://doi.org/10.1016/j. bbrc.2018.10.073

114. Xu H, Somers ZB, Robinson ML, Hebert MD (2005) Tim50a, a nuclear isoform of the mitochondrial Tim50, interacts with proteins involved in snRNP biogenesis. BMC Cell Biol 6:29. https://doi.org/10.1186/1471-2121-6-29

115. Callegari S, Cruz-Zaragoza LD, Rehling P, Rehling P (2020) From TOM to the TIM23 complex - handing over of a precursor. Biol Chem 401:709-721. https://doi.org/10.1515/hsz-2020-0101

116. Pagliardini S, Giavazzi A, Setola V et al (2000) Subcellular localization and axonal transport of the survival motor neuron $(\mathrm{SMN})$ protein in the developing rat spinal cord. Hum Mol Genet 9:47-56. https://doi.org/10.1093/hmg/9.1.47

117. Béchade C, Rostaing P, Cisterni C et al (1999) Subcellular distribution of survival motor neuron $(\mathrm{SMN})$ protein: possible involvement in nucleocytoplasmic and dendritic transport. Eur J Neurosci 11:293-304. https://doi.org/10.1046/j.1460-9568.1999. 00428.x

118. La Bella V, Kallenbach S, Pettmann B (2000) Expression and subcellular localization of two isoforms of the survival motor neuron protein in different cell types. J Neurosci Res 62:346-356. https://doi.org/10.1002/1097-4547(20001101)62:3\%3c346::AIDJNR4\%3e3.0.CO;2-D

119. Upadhyay A, Hosseinibarkooie S, Schneider S et al (2019) Neurocalcin delta knockout impairs adult neurogenesis whereas half reduction is not pathological. Front Mol Neurosci 12:19. https:// doi.org/10.3389/fnmol.2019.00019

120. Boos F, Labbadia J, Herrmann JM (2020) How the mitoproteininduced stress response safeguards the cytosol: a unified view. Trends Cell Biol 30:241-254. https://doi.org/10.1016/j.tcb.2019. 12.003

121. Gioran A, Chondrogianni N (2020) Mitochondria (cross)talk with proteostatic mechanisms: focusing on ageing and neurodegenerative diseases. Mech Ageing Dev 190:111324. https://doi. org/10.1016/j.mad.2020.111324

122. Wiese KE, Nusse R, van Amerongen R (2018) Wnt signalling: conquering complexity. Development 145:dev165902. https:// doi.org/10.1242/dev.165902

123. Bernkopf DB, Jalal K, Brückner M et al (2018) Pgam5 released from damaged mitochondria induces mitochondrial biogenesis via Wnt signalling. J Cell Biol 217:1383-1394. https://doi.org/ 10.1083/jcb.201708191

124. Rauschenberger V, Bernkopf DB, Krenn S et al (2017) The phosphatase Pgam5 antagonizes Wnt/ $\beta$-catenin signalling in embryonic anterior-posterior axis patterning. Development 144:22342247. https://doi.org/10.1242/dev.144477

125. Chen G, Han Z, Feng D et al (2014) A regulatory signalling loop comprising the PGAM5 phosphatase and CK2 controls receptormediated mitophagy. Mol Cell 54:362-377. https://doi.org/10. 1016/j.molcel.2014.02.034

126. Wu H, Xue D, Chen $\mathrm{G}$ et al (2014) The BCL2L1 and PGAM5 axis defines hypoxia-induced receptor-mediated mitophagy. Autophagy 10:1712-1725. https://doi.org/10.4161/auto.29568

127. Hubers L, Valderrama-Carvajal H, Laframboise J et al (2011) $\mathrm{HuD}$ interacts with survival motor neuron protein and can rescue spinal muscular atrophy-like neuronal defects. Hum Mol Genet 20:553-579. https://doi.org/10.1093/hmg/ddq500

128. Le Hao T, Duy PQ, An M et al (2017) HuD and the survival motor neuron protein interact in motoneurons and are essential for motoneuron development, function, and mRNA regulation. J Neurosci 37:11559-11571. https://doi.org/10.1523/JNEUR OSCI.1528-17.2017

129. Hong Y, Tak H, Kim C et al (2020) RNA binding protein HuD contributes to $\beta$-cell dysfunction by impairing mitochondria dynamics. Cell Death Differ 27:1633-1643. https://doi.org/10. 1038/s41418-019-0447-x

130. Groen EJN, Gillingwater TH (2015) UBA1: at the crossroads of ubiquitin homeostasis and neurodegeneration. Trends Mol Med 21:622-632. https://doi.org/10.1016/j.molmed.2015.08. 003

131. Anding AL, Wang C, Chang TK et al (2018) Vps13D encodes a ubiquitin-binding protein that is required for the regulation of mitochondrial size and clearance. Curr Biol 28:287-295. https:// doi.org/10.1016/j.cub.2017.11.064

132. Jády BE, Ketele A, Kiss T (2018) Dynamic association of human mRNP proteins with mitochondrial tRNAs in the cytosol. RNA 24:1706-1720. https://doi.org/10.1261/rna.066738.118

133. Hua Y, Vickers TA, Okunola HL et al (2008) Antisense masking of an hnRNP A1/A2 intronic splicing silencer corrects SMN2 splicing in transgenic mice. Am J Hum Genet 82:834-848. https://doi.org/10.1016/j.ajhg.2008.01.014

134. Guha M, Hua P, Fang JK, Avadhani NG (2009) Heterogeneous nuclear ribonucleoprotein $\mathrm{A} 2$ is a common transcriptional coactivator in the nuclear transcription response to mitochondrial respiratory stress. Mol Biol Cell 20:4107-4119. https://doi.org/ 10.1091/mbc.E09-04-0296 
135. Chen C, Turnbull DM, Reeve AK (2019) Mitochondrial dysfunction in Parkinson's disease-cause or consequence? Biology (Basel) 8:38. https://doi.org/10.3390/biology8020038

136. Wang W, Zhao F, Ma X et al (2020) Mitochondria dysfunction in the pathogenesis of Alzheimer's disease: recent advances. Mol Neurodegener 15:30. https://doi.org/10.1186/ s13024-020-00376-6

137. Chandel NS (2014) Mitochondria as signalling organelles. BMC Biol 12:34. https://doi.org/10.1186/1741-7007-12-34

138. Mottis A, Herzig S, Auwerx J (2019) Mitocellular communication: shaping health and disease. Science 366:827-832. https:// doi.org/10.1126/science.aax3768

139. Tan JX, Finkel T (2020) Mitochondria as intracellular signalling platforms in health and disease. J Cell Biol 219:e202002179. https://doi.org/10.1083/jcb.202002179

140. Owusu-Ansah E, Yavari A, Mandal S, Banerjee U (2008) Distinct mitochondrial retrograde signals control the G1-S cell cycle checkpoint. Nat Genet 40:356-361. https://doi.org/10.1038/ng. 2007.50

141. Wang Z, Fan M, Candas D et al (2014) Cyclin B1/Cdk1 coordinates mitochondrial respiration for cell-cycle G2/M progression. Dev Cell 29:217-232. https://doi.org/10.1016/j.devcel.2014.03. 012

142. Han Y, Ishibashi S, Iglesias-Gonzalez J et al (2018) $\mathrm{Ca}^{2+}$-induced mitochondrial ROS regulate the early embryonic cell cycle. Cell Rep 22:218-231. https://doi.org/10.1016/j.celrep.2017.12.042

143. Kasahara A, Cipolat S, Chen Y et al (2013) Mitochondrial fusion directs cardiomyocyte differentiation via calcineurin and notch signalling. Science 342:734-737. https://doi.org/10.1126/scien ce. 1241359

144. Iwata R, Casimir P, Vanderhaeghen P (2020) Mitochondrial dynamics in postmitotic cells regulate neurogenesis. Science 369:858-862. https://doi.org/10.1126/science.aba9760

145. Pérez MJ, Quintanilla RA (2017) Development or disease: duality of the mitochondrial permeability transition pore. Dev Biol 426:1-7. https://doi.org/10.1016/j.ydbio.2017.04.018

146. Bordet T, Berna P, Abitbol JL, Pruss RM (2010) Olesoxime (TRO19622): a novel mitochondrial-targeted neuroprotective compound. Pharmaceuticals (Basel) 3:345-368. https://doi.org/ 10.3390/ph3020345

147. Bertini E, Dessaud E, Mercuri E et al (2017) Safety and efficacy of olesoxime in patients with type 2 or non-ambulatory type 3 spinal muscular atrophy: a randomised, double-blind, placebocontrolled phase 2 trial. Lancet Neurol 16:513-522. https://doi. org/10.1016/S1474-4422(17)30085-6

148. Semenza GL, Roth PH, Fang HM, Wang GL (1994) Transcriptional regulation of genes encoding glycolytic enzymes by hypoxia-inducible factor 1. J Biol Chem 269:23757-23763

149. Li X, Jiang Y, Meisenhelder J et al (2016) Mitochondria-translocated PGK1 functions as a protein kinase to coordinate glycolysis and the TCA cycle in tumorigenesis. Mol Cell 61:705-719. https://doi.org/10.1016/j.molcel.2016.02.009

150. Picard M, McEwen BS, Epel ES, Sandi C (2018) An energetic view of stress: focus on mitochondria. Front Neuroendocrinol 49:72-85. https://doi.org/10.1016/j.yfrne.2018.01.001

151. Chali F, Desseille C, Houdebine L et al (2016) Long-term exercise-specific neuroprotection in spinal muscular atrophy-like mice. J Physiol 594:1931-1952. https://doi.org/10.1113/JP271 361

152. Bartels B, Montes J, Van Der Pol WL, De Groot JF (2019) Physical exercise training for type 3 spinal muscular atrophy. Cochrane Database Syst Rev 3:CD012120. https://doi.org/10.1002/14651 858.CD012120.pub2

153. Moore GE, Lindenmayer AW, McConchie GA et al (2016) Describing nutrition in spinal muscular atrophy: a systematic review. Neuromuscul Disord 26:395-404. https://doi.org/10. 1016/j.nmd.2016.05.005

154. Markowicz-Piasecka M, Sikora J, Szydłowska A et al (2017) Metformin - a future therapy for neurodegenerative diseases: theme: drug discovery, development and delivery in Alzheimer's disease guest editor: Davide Brambilla. Pharm Res 34:2614 2627. https://doi.org/10.1007/s11095-017-2199-y

155. Andrade S, Ramalho MJ, Pereira MDC, Loureiro JA (2018) Resveratrol brain delivery for neurological disorders prevention and treatment. Front Pharmacol 9:1261. https://doi.org/10.3389/ fphar.2018.01261

156. Murphy MP, Hartley RC (2018) Mitochondria as a therapeutic target for common pathologies. Nat Rev Drug Discov 17:865886. https://doi.org/10.1038/nrd.2018.174

157. Weissig V (2020) Drug development for the therapy of mitochondrial diseases. Trends Mol Med 26:40-57. https://doi.org/ 10.1016/j.molmed.2019.09.002

158. Hong N (2019) Photobiomodulation as a treatment for neurodegenerative disorders: current and future trends. Biomed Eng Lett 9:359-366. https://doi.org/10.1007/s13534-019-00115-x

159. Yang L, Youngblood H, Wu C, Zhang Q (2020) Mitochondria as a target for neuroprotection: role of methylene blue and photobiomodulation. Transl Neurodegener 9:19. https://doi.org/10. 1186/s40035-020-00197-z

160. Serrage HJ, Joanisse S, Cooper PR et al (2019) Differential responses of myoblasts and myotubes to photobiomodulation are associated with mitochondrial number. J Biophotonics 12:e201800411. https://doi.org/10.1002/jbio.201800411

161. Wang R, Dong Y, Lu Y et al (2019) Photobiomodulation for global cerebral ischemia: targeting mitochondrial dynamics and functions. Mol Neurobiol 56:1852-1869. https://doi.org/10.1007/ s12035-018-1191-9

162. Ferraresi C, Kaippert B, Avci P et al (2015) Low-level laser (light) therapy increases mitochondrial membrane potential and ATP synthesis in C2C12 myotubes with a peak response at 3-6 h. Photochem Photobiol 91:411-416. https://doi.org/10.1111/php. 12397

163. Chang SY, Lee MY, Chung PS et al (2019) Enhanced mitochondrial membrane potential and ATP synthesis by photobiomodulation increases viability of the auditory cell line after gentamicininduced intrinsic apoptosis. Sci Rep 9:19248. https://doi.org/10. 1038/s41598-019-55711-9

164. Hamblin MR (2018) Mechanisms and mitochondrial redox signalling in photobiomodulation. Photochem Photobiol 94:199212. https://doi.org/10.1111/php.12864

165. Vanin AA, Verhagen E, Barboza SD et al (2018) Photobiomodulation therapy for the improvement of muscular performance and reduction of muscular fatigue associated with exercise in healthy people: a systematic review and meta-analysis. Lasers Med Sci 33:181-214. https://doi.org/10.1007/s10103-017-2368-6

166. Zhang Z, Shen Q, Wu X et al (2020) Activation of PKA/SIRT1 signalling pathway by photobiomodulation therapy reduces $\mathrm{A} \beta$ levels in Alzheimer's disease models. Aging Cell 19:e13054. https://doi.org/10.1111/acel.13054

167. McCully JD, Levitsky S, del Nido PJ, Cowan DB (2016) Mitochondrial transplantation for therapeutic use. Clin Transl Med 5:16. https://doi.org/10.1186/s40169-016-0095-4

168. Gollihue JL, Rabchevsky AG (2017) Prospects for therapeutic mitochondrial transplantation. Mitochondrion 35:70-79. https:// doi.org/10.1016/j.mito.2017.05.007

169. Bertero E, Maack C, O'Rourke B (2018) Mitochondrial transplantation in humans: "magical" cure or cause for concern? J Clin Investig 128:5191-5194. https://doi.org/10.1172/JCI124944

170. Lightowlers RN, Chrzanowska-Lightowlers ZM, Russell OM (2020) Mitochondrial transplantation-a possible therapeutic 
for mitochondrial dysfunction? EMBO Rep 21:e50964. https:// doi.org/10.15252/embr.202050964

171. Rogers RS, Bhattacharya J (2013) When cells become organelle donors. Physiology 28:414-422. https://doi.org/10.1152/physiol. 00032.2013

172. Hayakawa K, Esposito E, Wang X et al (2016) Transfer of mitochondria from astrocytes to neurons after stroke. Nature 535:551-555. https://doi.org/10.1038/nature18928

173. Babenko VA, Silachev DN, Zorova LD et al (2015) Improving the post-stroke therapeutic potency of mesenchymal multipotent stromal cells by cocultivation with cortical neurons: the role of crosstalk between cells. Stem Cells Transl Med 4:1011-1020. https://doi.org/10.5966/sctm.2015-0010

Publisher's Note Springer Nature remains neutral with regard to jurisdictional claims in published maps and institutional affiliations. 